Kwartalnik Historyczny

Vol. CXXVII, 2020

Eng.-Language Edition no. 4, pp. 5-46

PL ISSN 0023-5903

RADOSŁAW KOTECKI

https://orcid.org/0000-0002-6757-9358

Kazimierz Wielki University in Bydgoszcz

JACEK MACIEJEWSKI

https://orcid.org/0000-0003-0505-975X

Kazimierz Wielki University in Bydgoszcz

\title{
IDEALS OF EPISCOPAL POWER, LEGAL NORMS AND MILITARY ACTIVITY OF THE POLISH EPISCOPATE BETWEEN THE TWELFTH- AND FOURTEENTH CENTURIES*
}

Abstract: This article is an attempt to illustrate relations between the theory and practice of the military activity of Polish bishops under the rule of the Piast dynasty. The problem is discussed based on an analysis of the locally formulated ideal of episcopal power and the ideological and legal patterns reaching Poland that regulated the possibilities of using weapons by clergymen, and, in particular, defined the ways in which churchmen participated in wars and in declaring and conducting them.

Keyw ords: bishops and war; warrior-bishop, ideals of episcopal power; canon law; clerical arms-bearing; episcopal warfare; Piast Poland.

Close relations between the clergy and the world of warriors and the undertaking of military tasks by clergymen were a frequent and well known phenomenon in the social and cultural landscape of western Christendom in the Middle Ages. Therefore, it is no wonder that bishops who held a prominent position in the ecclesiastical and social hierarchy, also conducted, for various reasons, significant military activity. In this article the problem is shown with respect to the military activity of the Polish bishops of the Piast era (until 1370). It is discussed here in the context of the ideal of episcopal power formulated in the church province of Gniezno and of ideological and legal patterns reaching these regions and regulating the possibilities of using arms by clergymen. In particular, it establishes more precisely the ways in which church hierarchs participated in wars, including their possibilities to declare them and personally conduct armed undertakings. Therefore it is an attempt to illustrate relations between

* The essy was supported by the Nacional Science Centre, Poland, under project number 2014/15/B/HS3-02284. 
theory and practice in the military activity of bishops in the local Polish Church. For such purposes Polish sources have been used to a minor extent, mainly due to the rather modest source evidence thereof and associated interpretive possibilities. But a more detailed query reveals accounts which have not been taken into account so far, and which, when treated together with those that are better known, seem to complement our knowledge on poorly known aspects of the cultural formation of the medieval Polish episcopate.

Researchers dealing with problems of episcopal power agree that the episcopate held an exceptional position in medieval society, with its activity far exceeding the religious and church-administrative area. ${ }^{1}$ Challenges facing bishops included involvement in armed activities or even conducting wars. ${ }^{2}$ In the Middle Ages this problem was vividly commented upon there were both opponents of bishops' participating in any kind of warfare and supporters of even far reaching personal military activity. In this article we want to ask what norms, formulated in this discussion, and ideals of episcopate power found their trace in the Polish source material registering the connections of the bishops of the ecclesiastical province of Gniezno with the military sphere. This problem has hitherto been dealt with only on the margin of discussions on constructing the vision of militarily active bishops based on the two oldest Polish chronicles, that is to say those of Gallus Anonymous and Master Vincentius. ${ }^{3}$ Our goal is to extend that per-

${ }^{1}$ For example, see Michel Parisse, 'The Bishop: Prince and Prelate', in The Bishop: Power and Piety at the First Millennium, ed. Sean Gilsdorf, Münster, 2004, pp. 1-22; Julia Barrow, The Clergy in the Medieval World: Secular Clerics, Their Families and Careers in North-Western Europe, c. 800-c. 1200, Cambridge, 2015; John S. Ott, Bishops, Authority, and Community in Northwestern Europe, c. 1050-1150, Cambridge, 2015. For Polish reality, see especially Jacek Maciejewski, Episkopat polski doby dzielnicowej, 1180-1320, Cracow and Bydgoszcz, 2003; also Józef Szymański, 'Biskupstwa polskie w wiekach średnich: Organizacja i funkcje”, in Kościół w Polsce, 2 vols, Cracow, 1968-70, vol. 1: Średniowiecze, ed. Jerzy Kłoczowski, Cracow, pp. 127-233.

${ }^{2}$ The secondary literature devoted to the problem of bishops' involvement in military matters has recently been summarized in the bibliography attached to the volume Between Sword and Prayer: Warfare and Medieval Clergy in Cultural Perspective, ed. Radosław Kotecki, Jacek Maciejewski and John S. Ott, Leiden and Boston, MA, 2018, pp. 517-30; see also the introductory chapter discussing research to date: Radosław Kotecki, Jacek Maciejewski and John S. Ott, 'The Medieval Clergy and War: A Historiographical Introduction', pp. 1-23.

${ }^{3}$ Radosław Kotecki, 'Ordynariusz płocki Szymon w Gallowej narracji o bitwie Mazowszan z Pomorzanami (Gall II, 49)', in Ecclesia et bellum: Kościół wobec wojny i zaangażowania militarnego duchowieństwa $w$ wiekach średnich, ed. Radosław Kotecki and Jacek Maciejewski, Bydgoszcz, 2016, pp. 142-67; idem, 'Aleksander z Malonne - "persona mixta”: Wojowniczy biskup na krańcach chrześcijańskiego świata i jego kronikarski portret', St. Źr., 55, 2017, pp. 1-78; idem, 'Lions and Lambs, Wolves and Pastors of the 
spective and attempt to find traces of patterns of bishop's military engagement also in later medieval sources. ${ }^{4}$ Due to the reconnaissance character of this study it is not possible to analyse all possible data, so we wish to focus on a selection of the most relevant evidence. We shall be particularly interested in information confirming the presence in the Polish episcopate of representatives with attitudes conflicting with the demand of separating bishops from war and arms. It must also be mentioned that we shall not focus on one of the more significant norms justifying bishops' military activity, that is, the requirement of service to the monarch. This problem is so broad that it requires a separate study, ${ }^{5}$ so we shall mainly focus on examples of bishops undertaking military tasks from an autonomous position, or at least those in which the role of monarch is not clearly indicated.

We are thus mainly interested in those examples which mention military means undertaken as a result of bishops' activity as church hierarchs. Limiting the area of interest in this way, we pose the question of what norms and ideals could in practice have an impact on the activity of bishops as clergymen. It is justified because most of the sources of interest to us come from the period when the Polish episcopate either aimed at making its position more autonomous or achieved a position relatively free from the sovereignty of Piast rulers. ${ }^{6}$ It should be remembered that the

Flock: Portraying Military Activity of Bishops in Twelfth-Century Poland', in Between Sword and Prayer, pp. 303-40; Jacek Maciejewski, 'A Bishop Defends His City, or Master Vincentius's Troubles with the Military Activity of His Superior', ibid., pp. 341-68; idem, 'Biskup krakowski Pełka a bitwa nad Mozgawą w 1195 roku', KH, 124, 2018, 3, pp. 411-38. Also Michał Tomaszek, 'Modlitwa i łzy bronią biskupa: Pasterze polskiego Kościoła a walka orężna w ujęciu Wincentego Kadłubka', RH, 71, 2005, pp. 121-36.

${ }^{4}$ The postulate regarding research on the ways of presenting episcopal office in Polish medieval narrative sources is still valid. The outdated work by Jan W. Góra, 'Sylwetka biskupa w XII i XII-wiecznej Polsce na podstawie kronik i żywotów świętych', Studia Teologiczno-Dogmatyczne, 4, 1984, pp.3-191 does not fill this gap. It has not been filled either by Włodzimierz Bielak’s book Biskup i jego urząd w oczach średniowiecznych kronikarzy polskich, Lublin, 2011, the value of this book has been summed up in a review by Marcin Rafał Pauk, PH, 104, 2014, 3, pp. 597-601. In both works the subject of episcopal military activity has been treated marginally.

${ }^{5}$ So far, see especially Marcin Rafał Pauk and Ewa Wółkiewicz, " Ministri enim altaris ministri curie facti sunt": Ottońsko-salicki "system" Kościoła Rzeszy i jego oddziaływanie w Europie Środkowej XI-XII wieku', in Kościół w monarchiach Przemyślidów i Piastów, ed. Józef Dobosz, Poznań, 2009, pp. 105-38 (pp. 116-19).

${ }^{6}$ More broadly: Maciejewski, Episkopat polski, pp. 130-59, where the older literature is cited. One should obviously be aware that this autonomy was not full. Even in the second half of the thirteenth century some princes tried to execute the rights resulting from their superior position toward bishops. See Winfried Irgang, " "Libertas ecclesiæ" und landesherrliche Gewalt - Vergleich zwischen dem Reich und Polen', in idem, Schlesien im Mittelalter: Siedlung - Kirche - Urkunden: ausgewählte 
current state of knowledge suggests that loosening relations between the episcopate and monarchs was a significant factor weakening bishops' connections with the military sphere, also, as we think, in the aspect which may be considered rooted in the pastoral duties of bishops. As we shall show below, this relationship never entirelly disappeared in medieval Poland, which constitutes an argument for its durable basis independent from the custom of court and state service, as well as duties resulting from the obligarions with regalia, that is, the duty of military service in exchange for secular goods and jurisdiction granted by the monarch.

I.

Before we proceed to discuss individual source accounts, let us ask, on what norms and ideals concerning bishops' involvement in military matters spread in the times of our interest, what tendencies did they follow, and what was their possible way into Poland. In the Polish historiography regarding to the Church of the Piast era, the significance of the reform efforts of Henry Kietlicz for shaping the new image of the Polish episcopate is stressed. These actions are even considered a caesura separating the period in which bishops were dependent on rulers' will and fulfilled the model of 'pre-Gregorian' bishop, ${ }^{7}$ from the period in which pro-reform attitudes were familiarized by bishops and increased their focus on pastoral tasks and activity in the ecclesiastical sphere. ${ }^{8}$ It has also been emphasized that the proper reception of Gregorian demands in Poland took place one century later than in west-

Aufsätze, ed. Norbert Kersken and Jürgen Warmbrunn, Marburg, 2007, pp. 182-208; idem, " "Libertas ecclesiæ" und landesherrliche Gewalt: Zur Kirchenpolitik der schlesischen Piasten im 13. Jahrhundert', ibid., pp. 158-81.

${ }^{7}$ Representative is the opinion of Stanisław Rosik, who noted that bishops at the times of Bolesław III Wrymouth, as pre-Gregorian formation bishops, took part in monarch's campaigns as warriors. Stanisław Rosik, Bolesław Krzywousty, Wrocław, 2013, p. 267.

${ }^{8}$ A serious problem for the proper evaluation of the meaning of Henry Kietlicz's activities is the insufficiently researched issue of the formation of Polish bishops and the Church until the end of the twelfth century. Recently, Marcin R. Pauk's research has brought valuable remarks on this issue. See especially Marcin Rafał Pauk, 'Capella regia i struktury Kościoła monarszego w Europie Środkowej X-XII wieku: Ottońsko-salickie wzorce ustrojowe na wschodnich rubieżach łacińskiego chrześcijaństwa', in Granica wschodnia cywilizacji zachodniej w średniowieczu, ed. Zbigniew Dalewski, Warsaw, 2014, pp. 211-77. Many still valid postulates were made by Marek Derwich, 'Relacje między monarchią i możnymi a Kościołem, czy: kto, kiedy i gdzie fundował najstarsze instytucje kościelne w Polsce? [na marginesie monografii Józefa Dobosza, Monarchia i możni wobec Kościoła w Polsce do początku XIII wieku]', RH, 68, 2002, pp. 195-205. 
ern Europe. ${ }^{9}$ But in fact the problem seems much more complex. First, the initiating role in this process has been too schematically ascribed to the Holy See and papal legates, forgetting that certain reform requirements - particularly those relating to moral formation and the clergy's way of life - could have been implemented earlier, to a certain degree by bishops themselves, sometimes in cooperation with monarchs and the secular elite.$^{10}$ Second, it is overlooked that there were many trends of church reform and in the second half of the twelfth and in the thirteenth century the vision of reform as radical as the one formulated by supporters of the Gregorian reform did not dominate anymore. The effect of this was, for example, the abandoning of some of the ideals accepted earlier. They included the idea of depriving clergy of the possibility to participate in warfare, which was soon considered as not being good for the reform and the struggle for the Church's independence from secular interference. ${ }^{11}$ Its position was clearly weakened not only as a result of the broad acceptance of the interpretation about the nature of regalia and the resulting duties

${ }^{9}$ See Józef Dobosz, 'Arcybiskup Janik i jego następcy: Przygotowanie do reformy Henryka Kietlicza', in 1000 lat Archidiecezji Gnieźnieńskiej, ed. Jerzy Strzelczyk and Janusz E. Górny, Gniezno, 2000, pp. 81-96, at p. 96 the very representative statement: 'The second half of the twelfth century undoubtedly formed a basis for the new Polish Church, which reformed itself internally in the Gregorian spirit'. The same opinion of Jerzy Wyrozumski, 'Pontyfikat arcybiskupi i reformy Henryka Kietlicza', ibid., pp. 97-105, pp. 99 f.: 'It is true that it did not deal [that is Henry Kietlicz's policies] at all with any new church ideas but with adjusting the Polish Church to the state which in western Europe had been reality for a long time and which had its source in the programme of Gregory VII'. Also, see Krzysztof Skwierczyński, 'Centrum i prowincja - rewolucja gregoriańska w Kościele powszechnym a reforma gregoriańska w Kościele polskim’, in Kościół w monarchiach Przemyślidów i Piastów, pp. 181-92; Wojciech Baran-Kozłowski, 'Reforma gregoriańska w Europie Środkowej za pontyfikatu Innocentego III', ibid., pp. 151-67; idem, 'Rola Stolicy Apostolskiej w działaniach reformatorskich arcybiskupa Henryka Kietlicza', in Sacri canones servandi sunt: Ius canonicum et status ecclesioe soculis XIII-XV, ed. Pavel Krafl, Prague, 2008, pp. 490-94.

10 See John Howe, 'The Nobility's Reform of the Medieval Church', AHR, 93, 1988, 2, pp. 317-39. About such phenomenon in Hungary, see Vincent Múcska, Uhorsko a cirkevné reformy 10. a 11. storočia, Brno, 2004. The example of St Vojtěch-Adalbert as a bishop of pro-reform attitude is equally symptomatic. See Roman Michałowski, 'Święty Wojciech biskup reformator w Europie X wieku’, in Granica wschodnia, pp. 169-210.

${ }^{11}$ Representative are opinions indicating that reform-minded popes, like Gregory VII, could not allow themselves to resign from military prerogatives held by bishops, since this would weaken their position. See, for example, Craig M. Nakashian, Warrior Churchmen of Medieval England, 1000-1250: Theory and Reality, Woodbridge, 2016, pp. $70 \mathrm{f}$. Regarding the fact that acceptance of reform did not automatically lead to bishops divesting themselves of military potential and the possibility to use it, see especially Robert Houghton, 'Italian Bishops and Warfare during the Investiture Contest: The Case of Parma', in Between Sword and Prayer, pp. 274-302. 
of prelates to monarchs, ${ }^{12}$ but also of the appearance of theoretical arguments justifying extended military competences of higher-ranking clergy. They include, primarily, the concept assuming possession by bishop of 'two swords' - spiritual and secular. This concept, very popular in the twelfth and thirteenth centuries not only in the church circles of the Reich, perfectly legitimized those armed actions which resulted from holding episcopal office and served the performance of ecclesiastical goals, or, especially, maintaining the integrity of the Church's landed properties or as a specific extension of a bishop's pastoral power (struggle against rebels, excommunicates and heretics, and so on). ${ }^{13}$ One can also see its permeation into the ideologies of the crusade and chivalry, which crystalized at that time. ${ }^{14}$

A very characteristic trend also appeared at that time in canon law. The condition of disarming clergy, firmly imposed by reformers, although it left its trace in statutes and collections of canon-law of the eleventh century, as early as in that century coexisted with the idea of admitting clergy to military matters, for example in the statements of such supporters of Gregory VII as Anselm of Lucca or Bonizo of Sutri. ${ }^{15}$ And such opinions were the backup of the specific liberalization of church law on clerical armsbearing, the evolution of which may be observed in the following century. We already see symptoms of it in Gratian's Decree written from

12 Among others, see Helena M. Chew, The English Ecclesiastical Tenants in Chief and Knight Service, Oxford, 1932; Gerard J. Campbell, 'Temporal and Spiritual Regalia during the Reigns of St. Louis and Philip III', Traditio, 20, 1964, pp. 351-83; Robert L. Benson, "The Obligations of Bishops with "Regalia": Canonistic Views from Gratian to the Early Thirteenth Century', in Proceedings of the Second International Congress of Medieval Canon Law, ed. Stephan Kuttner and Joseph Ryan, Vatican City, 1965, pp. 123-37; Johannes Fried, 'Der Regalienbegriff im 11. und 12. Jahrhundert', Deutsches Archiv für Erforschung des Mittelalters, 29, 1973, pp. 450-528; John W. Baldwin, The Government of Philip Augustus: Foundations of French Royal Power in the Middle Ages, Berkeley, CA, and Ann Arbor, CA, 1986, pp. 179 f.; Richard A. Fletcher, 'Regalian Right in Twelfth-Century Spain: The Case of Archbishop Martín of Santiago de Compostela', Journal of Ecclesiastical History, 28, 1977, 4, pp. 337-60; Everett U. Crosby, The King's Bishops: The Politics of Patronage in England and Normandy, 1066-1216, New York, 2013; Sophie T. Ambler, Bishops in the Political Community of England, 1213-1272, Oxford, 2017.

${ }^{13}$ Particularly Jan U. Keupp, 'Die zwei Schwerter des Bischofs: Von Kriegsherren und Seelenhirten im Reichsepiskopat der Stauferzeit', Zeitschrift für Kirchengeschichte, 117, 2006, pp. 1-24.

${ }^{14}$ Karl Villads Jensen, 'Bishops on Crusades', in 'Dominus Episcopus': Medieval Bishops between Diocese and Court, ed. Anthony John Lappin and Elena Balzamo, Stockholm, 2018, pp. 83-99.

${ }^{15}$ Carl Erdmann, The Origin of the Idea of Crusade, transl. Marshall W. Baldwin and Walter Goffart, Princeton, NJ, 1977, pp. 241-61; Kathleen Cushing, Papacy and Law in the Gregorian Revolution: The Canonistic Work of Anselm of Lucca, Oxford, 1998, pp. 129-38; Nakashian, Warrior Churchmen, pp. 66, 68 f., 72. 
the 1120 s, which in the middle of the twelfth century became very popular and a little later on it appeared in central European countries. ${ }^{16}$ According to the author of that collection, although the clergy, including bishops, should not fight in person, they could participate in military actions conducted by legal public authorities and for a clearly defined purpose compliant with what was then imagined about a just war, providing all necessary support. ${ }^{17}$ In any case, in connection with this canonists quickly began to consider whether also the pope and bishops themselves were entitled to declare and wage wars. Initially, especially if we took into account recognized authorities in canon law such as Paucapalea or Master Rolandus ${ }^{18}$ the answer to this question was negative. ${ }^{19}$ But at the same time Bernard of Clairvaux, although he was of the opinion that a bishop should avoid becoming a persona mixta, a clergyman and a layman in one person, he did not refuse them the right to conduct war, but did expect them to accept the principle that it should take into account the final spiritual goal. ${ }^{20}$ From the end of the twelfth century statements on this problem were more frequent, because the next generations of decretists and decretalists rather shared the opinion that church hierarchs had the power to declare war. Even Pope Innocent IV (1243-54), who was in fact against it, indicated exceptions from the rule. In his commentary to Decretals of Gregory IX he expressed the opinion that a clergyman might declare war in two cases: to defend himself, and

${ }^{16}$ It has been confirmed that Decree had been known in Poland since 1180 and in Bohemia since 1159. Adam Vetulani, 'Przenikanie zasad powszechnego prawa kanonicznego i prawa rzymskiego do piastowskiej Polski', in idem, Z badań nad kultura prawnicza w Polsce piastowskiej, Wrocław, 1976, pp. 95-128, (pp. 97 f.); Jiří Kejř , 'Pronikání kanonického práva do středověkého českého státu', Revue církevního práva, 8 , 1997, 3, pp. 137-56 (p. 138); Pavel Krafl, 'Prawo kościelne w Czechach i na Morawach w średniowieczu’, Echa Przeszłości, 11, 2010, pp.19-36 (p. 24).

${ }^{17}$ For example, Frederick K. Russell, The Just War in the Middle Ages, Cambridge, 1977; Ernst-Dieter Hehl, Kirche und Krieg im 12. Jahrhundert: Studien zu Kanonischem Recht und politischer Wirklichkeit, Stuttgart, 1980; Lawrence G. Duggan, Armsbearing and the Clergy in the History and Canon Law of Western Christianity, Woodbridge, 2013, pp. 128 f.; Nakashian, Warrior Churchmen, pp. $92 \mathrm{f}$.

${ }^{18}$ Who, nevertheless, should not be identified with the later Pope Alexander III. See John T. Noonan, 'Who Was Rolandus?', in Law, Church, and Society: Essays in Honor of Stephan Kuttner, ed. Kenneth Pennington and Robert Somerville, Philadelphia, PA, 1977, pp. 21-48, (pp. 43 f.); Rudolf Weigand, 'Magister Rolandus und Papst Alexander III', Archiv für katholisches Kirchenrecht, 149, 1980, pp. 3-44.

${ }^{19}$ James A. Brundage, 'Holy War and the Medieval Lawyers', in The Holy War, ed. Thomas Patrick Murphy, Columbus, OH, 1976, pp. 99-140 (p. 110).

${ }^{20}$ Alice Chapman, Sacred Authority and Temporal Power in the Writings of Bernard of Clairvaux, Turnhout, 2013, pp. 80, 156 f., 174 f.; Kotecki, 'Aleksander z Malonne', pp. $62 \mathrm{f}$; Jensen, 'Bishops on Crusades', pp. $83 \mathrm{f}$. 
to regain illegally seized church properties. He could not personally take part in it but he could encourage soldiers to fight and take prisoners of war. But in one of his decretals the pope approved the statement that any law allows people to repulse of violence with violence. ${ }^{21}$ The reasoning of the outstanding canonist Henry Segusio (called Hostiensis, died 1271) followed the same path; he maintained that church authorities might declare war against enemies of the Christian faith, and against those who attacked the Church and rebelled against it. ${ }^{22}$ According to Durandus (1230-96), if the cause of war was subject to ecclesiastical jurisdiction, each clergyman who had such jurisdiction was entitled to declare it. ${ }^{23}$ So we see that church legislation regarding this matter was not very clear for several centuries, but finally canonists began to grant the right to declare war to each person from the group of principes, therefore, each clergyman who held some kind of power over people. Not to mention that it was not completely clear how war was defined from legal point of view. Even if canonists understood it exclusively as the matter of public domain declared by legal authority, there were still several levels of power resulting from possessing land and performing jurisdiction over its inhabitants, to which bishops had undisputable right. ${ }^{24}$

Therefore, it seems that based on church law, eventually the only rule that was never questioned was the ban on personal use of arms by the clergy for offensive purposes, whereas any other activity connected with arms could be justified, and in certain circumstances even be considered laudable. If the goal of the war was righteous, especially if it was the defence of the Church, political community or Christian religion, a bishop could even take part in a battle without fear about his authority, if only he maintained a restrained attitude and was careful not to deal a blow any other way but in self-defence. ${ }^{25}$

II.

In connection with the tendencies observed at that time, the question arises of whether in Poland, in the period perceived as a special moment of the reception of reform ideals, there could occur conditions advanta-

${ }^{21}$ Brundage, 'Holy War', pp.110-11; Duggan, Armsbearing, p. 140.

${ }^{22}$ Brundage, 'Holy War', p. 111.

${ }^{23}$ Ibid.

${ }^{24}$ Duggan, Armsbearing, p. 145.

${ }^{25}$ Interesting examples in Michel Sot, 'Des évêques à la guerre (VIII'-XIIIe siècle)', in Guerre et société au Moyen Âge: Byzance - Occident (VIII $-X I I I^{e}$ siècle), ed. Dominique Barthélemy and Jean-Claude Cheynet, Paris, 2010, pp. 103-12. 
geous for the dissemination of norms demanding the clergy's abstinence from participation in military matters. Studies on this issue are to a large extent impeded by insufficient sources, which would allow us to state if in the local programme of reform there was place for such voices. This silence is rather suspicious and may be interpreted in two ways: as the effect of a lack of interest in this type of matters as a result of the minor military competences of Polish bishops, but also as an expression of reluctance to introduce norms limiting such competences. The second option may be more likely because we know the programme of Kietlicz's reform quite well, ${ }^{26}$ but at the same time we know that the archbishop had a penchant for modelling his authority not on the model of a humble priest but of a lordly prelate ostentatiously referring to the political power of the Holy See. ${ }^{27}$ We must interpret in this way accusations against him, such as information about keeping a large retinue that can be compared only to ducal retinues. ${ }^{28}$ It is unlikely that a clergyman with such political ambitions and programme aimed at strengthening his position in state politics would write on his banners the postulate of separating bishops from war matters and making them pastors only. That was even not expected from him by his most important ally and co-operator, Innocent III, ${ }^{29}$ and was not demanded by canons of the IV Lateran Council - rather liberal in this matter - brought by the archbishop from Rome..$^{30}$ There is no need to add that such activity would rather not facilitate accomplishment of the goal, that is the consolidation of the Polish episcopate under the supervision of the archbishop and focusing on the programme of struggle for the independence of the Church from secular authorities.

${ }^{26}$ Wyrozumski, ‘Pontyfikat arcybiskupi',pp. 97-105; Wojciech Baran-Kozłowski, Arcybiskup gnieźnieński Henryk Kietlicz (1199-1219): Działalność kościelna i polityczna, Poznań, 2005, pp. 119-85.

${ }_{27}$ See particularly Paweł Stróżyk, 'Monogram z roty arcybiskupa gnieźnieńskiego Henryka Kietlicza z 1208 roku', RH, 77, 2011, pp. 169-81.

${ }^{28}$ No doubt it must have been a retinue composed to some extent of armed men, maybe with the status of ministerials. See Jan Szymczak, 'W kwestii liczebności oddziałów wojskowych w Polsce okresu rozbicia dzielnicowego', Acta Universitatis Lodziensis. Folia Historica, 2, 1981, pp. 51-75 (p. 60).

${ }^{29}$ On the permissive attitude of Innocent III toward warrior prelates and clerical crusaders, see Nakashian, Warrior Churchmen, p. 234. It is also worth stressing that Kietlicz himself planned to lead Polish troops to the Holy Land. Darius von Güttner-Sporzyński, Poland, Holy War, and the Piast Monarchy, 1100-1230, Turnhout, 2014, p. 194.

${ }^{30}$ For more on this, see Duggan, Armsbearing, pp. 125, 134; idem, 'Armsbearing by the Clergy and the Fourth Lateran Council', in The Fourth Lateran Council and the Development of Canon Law and the 'ius commune', ed. Andrea Massironi and Atria A. Larson, Turnhout, 2018, pp. 63-75. 
The presence in Kietlicz's programme of other major reform ideals does not necessarily suggest he wanted to limit the military prerogatives of hierarchs of the Polish Church. As Craig M. Nakashian recently indicated, although reformers initially placed the matter of clergy's abstinence from arms and war next to the demand to separate clergymen from contacts with women or elimination of simony, in practice this problem, especially if we speak about bishops, has taken another place. No traces of attempts to remove warrior-like prelates from office are noticed, as occurred with simoniacal bishops or those who openly broke the rule of celibacy. ${ }^{31}$ The fact that these matters were not treated equally is shown in examples of bishops famous for their martial accomplishments but who at the same time were patrons of the moral renewal of the clergy. This is best illustrated in the activity of the most famous warrior-bishop in the Baltic Sea region, a contemporary of Kietlicz, Absalon, archbishop of Lund..$^{32}$ Equally characteristic in this respect is the example of the papal legate who took part in a synod in Valladolid in 1228, and in a report sent to Pope Gregory IX he wrote much about the Castilian clergy's bent for women, but was not interested at all in the well-known eagerness of that clergy for war. ${ }^{33}$ In this context it is worth recalling that in Poland the principle of celibacy was introduced by the bishop of Wrocław, Walter, in his diocese; he was the brother of Alexander, bishop of Płock, who was considered a warrior and with whom he probably shared his intellectual formation and notion of episcopal duties. ${ }^{34}$

${ }^{31}$ Nakashian, Warrior Churchmen, pp. 65-66, 88, 172.

${ }^{32}$ Cf. Anthony Perron, 'Saxo Grammaticus's Heroic Chastity: A Model of Clerical Celibacy and Masculinity in Medieval Scandinavia', in Negotiating Clerical Identities: Priests, Monks and Masculinity in the Middle Ages, ed. Jennifer D. Thibodeaux, Basingstoke and New York, 2010, pp. 113-35. On Absalon, see Niels Lund, 'Absalon som kriger og politiker', in Absalon: Foedrelandets fader, ed. Frank Birkebæk, Tom Christensen and Inge Skovgaard-Petersen, [Roskilde], 1996, pp. 73-90; Helle Vogt, 'Absalon: évêque, guerrier et le Richelieu du Danemark', in Autour de Lanfranc (1010-2010): Réforme et réformateurs dans l'Europe du Nord-Ouest (XI ${ }^{e}-X I^{e}$ siècles), ed. Julia Barrow, Fabrice Delivré and Véronique Gazeau, Caen, 2015, pp. 329-42.

33 Ana Arranz Guzmán, 'Cuando el clérigo va a la guerra: algunos ejemplos de obispos “peleadores”, in Guerra y paz en la Edad Media, ed. Ana Arranz Guzmán, María del Pilar Rábade Obradó and Óscar Villarroel Gonzáles, Madrid, 2013, pp. 275-308 (pp. 276 f.).

${ }^{34}$ For more about the reform policy of Walter, see Jean Hockay, 'Alexandre et Gauthier: Deux Malonnois en Pologne, au XIIe siècle', Guetteur Wallon, 54, 1978, 3, pp. 81-95 (pp. 83 f.); Piotr Boroń, 'Biskup wrocławski Walter i początki kultury umysłowej na Śląsku', in Źródła kultury umysłowej w Europie Środkowej ze szczególnym uwzględnieniem Górnego Śląska, ed. Antoni Barciak, Katowice, 2005, pp. 115-32. 
The same may be said about the idea of libertatis ecclesice promoted by Kietlicz. From the eleventh century onwards bishops commonly used this idea in trying to limit the scope of domination of the secular authorities over local churches, including the limitation of the military duties of the clergy for the secular authorities. Nevertheless, the aim of accompanying efforts were to maintain the high political position that bishops achieved under monarch's patronage, and nothing indicates that the goal or even side effects of these attempts was a noticeable decrease of the military potential of bishops and bishoprics. The high Middle Ages, especially the thirteenth century, was a period in which in spite of acceptance of certain reform requirements, such as celibacy and the independence of the Church from secular interference, bishops in the West reached the peak of their powers and defended this position with the help of no less impressive military resources and political influence. ${ }^{35}$ The status of Polish bishops is not impressive against the western background, but it should be emphasized that they also continued to try to increase their political significance and from the second half of the eleventh century evidence can be found confirming their position in the local structures of power, ${ }^{36}$ and in the twelfth century, especially in the following century, bishops managed to strengthen their political influence in spite of the gradually loosening links with the secular authorities. One may assume that tendencies which we observe at that time constitute a certain parallel to the situation in the politically divided Empire. Obviously, Polish bishops could not equal the clerical princes of the Reich with respect to their secular potential, but one may doubt that the situation under the rule of the Staufen dynasty was overlooked by them and was not a point of reference in shaping their own position and identity. As a clear trace of following the patterns coming from the West one may consider the endeavour of Polish bishops to possess of spiritual-territorial principalities. It is also possible that bishops' formation in thirteenth-century Poland was affected by a tendency - analogical to

${ }^{35}$ Cf. Matthew M. Mesley, 'Beyond Celibacy: Medieval Bishops, Power and Masculinity in the Middle Ages', in The Palgrave Handbook of Masculinity and Political Culture in Europe, ed. Christopher Fletcher et al., London, 2018, pp. 133-60. On the political position of German bishops at that time, see Benjamin Arnold, Count and Bishop in Medieval Germany, Philadelphia, PA, 1991; Stefan Burkhardt, Mit Stab und Schwert: Bilder, Träger und Funktionen erzbischöflicher Herrschaft zur Zeit Kaiser Friedrich Barbarossas: Die Erzbistümer Köln und Mainz im Vergleich, Ostfildern, 2008.

${ }^{36}$ Marcin Rafał Pauk, “"Quicquid pertinebat ad imperium”: Kościół w Polsce a Rzesza do połowy XII wieku', in Chrzest Mieszka I i chrystianizacja państwa Piastów, ed. Józef Dobosz, Jerzy Strzelczyk and Marzena Matla-Kozłowska, Poznań, 2017, pp. 249-80 (p.266). 
the one in Reich and other western monarchies - to secularize the episcopal ideal and place political involvement over religious tasks. ${ }^{37}$ The statutes of Wrocław legatine synods from 1248 and 1264, which condemned certain bishops of the Gniezno province for neglecting their pastoral duties may be a kind of trace of the development of the aforementioned trends. ${ }^{38}$

\section{III.}

The intellectual atmosphere of discussion and noticeable favour for military prerogatives of bishops presented above is difficult to find in the general run of sources relating to Poland. Nevertheless, it is possible to point out examples suggesting the development in Poland of military competences belonging to the position of bishop, which exceeded the requirement of participation in the monarch's campaigns or those connected with the mustering of armed troops upon the monarch's call. ${ }^{39}$ The list begins with Gallus's information on the participation of Bishop Simon in actions carried out by the Mazovian comes Magnus against the invading Pomeranians. ${ }^{40}$ Although Simon was presented in this narrative as a man of spirit, who fought against the invaders with prayers and not with material weapons, Gallus did not hide the fact that the bishop played in these actions the role equal to the one played by the provincial governor, as his peculiar spiritual alter ego. Special attention was turned to the fact that the prisoners of war were brought to stand before the governor and the bishop so that they could together decide about their fate, which clearly indicates an equal and complementary

${ }^{37}$ This problem requires deepened research. The situation in the Reich should constitute a natural background for considerations. Cf. Thomas Wünsch, 'Der heilige Bischof - Zur politischen Dimension von Heiligkeit im Mittelalter und ihrem Wandel', Archiv für Kulturgeschichte, 82, 2000, 2, pp. 261-302, who noticed that bishops' departure from the emperor's service and the desacralization of the monarch's persona also led to the secularization of bishops' position and its transformation toward ducal power.

${ }^{38}$ Although a certain legate's charges did not reflect reality, especially geographical, in which the Polish Church operated. See Maciejewski Episkopat polski, pp. $206 \mathrm{f}$. Polemically, but with no arguments a contrario, see Stefan Kwiatkowski, 'Utracona wiarygodność statutów Jakuba z Leodium', Klio, 7, 2005, 7, pp. 159-64.

${ }^{39}$ On the matters dealt with in this paragraph below, see our papers on the accounts by Gallus Anonymous and Master Vincentius cited above in footnote 3. Also Radosław Kotecki and Jacek Maciejewski, 'Writing Episcopal Courage in Twelfth-Century Poland: Gallus Anonymous and Master Vincentius', in Episcopal Power and Personality in Medieval Europe, 900-1480, ed. Peter Coss et al., Turnhout, 2020, pp. 35-61.

${ }^{40}$ Galli Anonymi Cronicae et gesta ducum sive principium Polonorum, ed. Karol Maleczyński, Cracow, 1952, pp. 118 f. (Book II, Chapter 49), MPH s.n., vol. 2. 
responsibility of these two characters. Simon's portrait is undoubtedly affected by the reform formation of Gallus himself, but the text also reveals familiarity with the custom established in the West, especially in the domains of the Carolingian and Ottonian dynasties, of close cooperation between counts and bishops in combating threats from the external, especially pagan invaders. ${ }^{41}$

The message provided by Vincentius about the same Bishop Simon and his successor, Alexander of Malonne, goes even further. ${ }^{42}$ Here bishops are completely autonomous in their activities. The figure of Magnus as Simon's companion disappears, whereas Alexander is presented as an independent leader of the local community (dux gregis), a commander of knights and a real mainstay of Mazovia - disturbed by invading Prussians. Furthermore, Vincentius ascribed similar competences - although in a more veiled form - to his superior, Bishop Pełka of Cracow, who was presented as the chief commander of the allied Cracovian and Ruthenian army during the expedition against forces of Mieszko III near Mozgawa, and as a defender of the capital city, and, therefore, of the surrounding region. It is true that in Vincentius's work none of bishops personally used arms or spilled blood, preferring spiritual arms, but it is striking that the chronicler had no problem in presenting them as independent decision-makers in war matters, responsible for the security of all regions and territorial communities. Nevertheless, we learn most from the commentary in which the chronicler described the activities of Alexander of Płock; it shows that Vincentius was familiar with the intellectual debate on a bishop's role in military actions. The way in which Vincentius described Alexander demonstrates his familiarity with arguments used at that time to justify the extensive military competences of bishops, which we know, for example, from works written in the Reich, England, Spain or the territories of the Holy Land, but the same time it may reveal the perception of these issues in the chronicler's milieu. One should also bear in mind that in this respect though more because of broad argumentation than general message Vincentius's approach is presented against the background of Polish historiography as an isolated one. However, this fact does not decrease its value, especially in the context of recently noticed information by Jan Długosz

${ }^{41}$ See Simon Coupland, 'The Carolingian Army and the Struggle against the Vikings', Viator, 35, 2004, pp. 49-70; Geneviève Bührer-Thierry, 'Des évêques sur la frontière: Christianisation et sociétés de frontière sur les marches du monde germanique aux $\mathrm{X}^{\mathrm{e}}-\mathrm{XI}{ }^{\mathrm{e}}$ siècle’, Qucestiones Medii Ævi Novce, 16, 2011, pp. 61-80; eadem, 'Bishops as City Defenders in Early Medieval Gaul and Germany', in Between Sword and Prayer, pp. 24-45.

${ }^{42}$ Magistri Vincentii dicti Kadłubek Chronica Polonorum, ed. Marian Plezia, Cracow, 1994, pp. 92-94 (Book III, Chapter 8), MPH s.n., vol. 11. 
about the later bishops of Płock, Gedka Sasinowic and Gunter, which were based on older (probably from the thirteenth century), lost historical sources. It is important to note that Długosz's accounts reveal very similar views about the episcopal role in the context of warfare. ${ }^{43}$

Taking all these evidences into account, we see that authors who wrote in Poland in the twelfth and first decades of the thirteenth century knew the model of episcopal actions corresponding with legal norms characteristic for liberalizing trend in canon law, with which corresponded the conviction about the two types of arms at the disposal of bishop. In spite of our knowledge about close relations of the episcopate with princes, these examples also make us perceive bishops of that time as persons with an extensive practical scope of responsibility and quite a large degree of independence in performing their mission. Not accidentally, such a situation corresponds to the model figures of bishops of the early medieval era and fits the observations of Timothy Reuter, who stressed that until the time of papal centralization of the Church, bishops - in spite of certain duties toward secular rulers, archbishops and the pope - enjoyed wide autonomy and responsibility in the management of their dioceses and resources. ${ }^{44}$

Nevertheless, it should be emphasized that all the above mentioned approaches both separate bishops from the direct contact with arms, and clearly expressed the conviction that all these military actions are legal if aimed at providing protection to local communities, to which bishops were both spiritual fathers and superiors. Master Vincentius presented this view in the spirit of Gregory the Great's opinion, popular in the Middle Ages, as a manifestation of the external duties of bishops. ${ }^{45}$ This means that the

${ }^{43}$ For more on Długosz's narratives, see Jacek Maciejewski, 'Memory of "Warrior-Bishops” of Płock Included into Jan Długosz's Works', in Christianity and War in Medieval East Central Europe and Scandinavia, ed. Radosław Kotecki, Carsten Selch Jensen and Stephen Bennett, Leeds, 2021 (in print).

${ }^{44}$ Timothy Reuter, 'A Europe of Bishops: The Age of Wulfstan of York and Burchard of Worms', in Patterns of Episcopal Power: Bishops in Tenth and Eleventh Century Western Europe, ed. Lutger Körntgen and Dominik Waßenhoven, Berlin and Boston, MA, 2011, pp.17-38.

${ }^{45}$ The Płock cathedral built by the bishop, and in chronicler's view undoubtedly symbolizing the entire Mazovian church, was supposed to be armed inside with spiritual knights, and outside with the secular knighthood: Magistri Vincentii Chronica, pp. 93 f. (Book III, Chapter 8): 'Ipsa operis elegantia, forme festiuitas dulcissimo illum cordis palato indesinenter ostendit masticasse: Domine, dilexi decorem domus tue, quam non tantum intrinsecus ac spiritualibus locupletauit studiis, set etiam armis communiuit materialibus, necesariis undiquue septam presidiis, ut lectulum Salomonis et LX ex fortissimis filiorum Israel intrinsecus et CCC ex electissimis loricatorum extrinsecus custodirent'. For similar arguments used by Saxo Grammaticus justifying the armed activity of Archbishop Absalon, see Saxo Grammaticus, Gesta Danorum, 2 vols, ed. Karsten 
military bases of episcopal power in Piast-era Poland, until the first decades of the thirteenth century, were modeled after the pattern of the state church. This, in turn, makes one suspect that at that time Polish bishops had large military competences, which they could use if undertaken actions found justification on the ground of pastoral and state responsibilities, which until that time still overlapped with each other to a large extent. ${ }^{46}$ This probably enables us to understand better the lack of demands regarding the limitation of these competences in the local programme of church reform. ${ }^{47}$

IV.

While sources relating to the twelfth century and first decades of the thirteenth century present the military activity of bishops as appropriate and justified by pastoral duties, it is much more difficult to evaluate how such activity was perceived later and how bishops themselves shaped their military prerogatives with the progressing empowerment

Friis-Jensen, Oxford, 2015, here vol. 2, p. 1116 (Book XIV, Chapter 21.3): 'Qui mox antistes creatus non minus piratam se quam pontificem gessit, parui estimans intus religionem tueri, si foris eam periclitari pateretur. Neque enim minus sacrorum attinet cultui publice religionis hostes repellere quam ceremoniarum tutele uacare'. Compare Gregorii Magni Liber reguloe pastoralis, ed. Jacques-Paul Migne, in PL, vol. 77, column 38: 'Sit rector internorum curam in exteriorum occupatione non minuens, exteriorum providentiam in internorum sollicitudine non relinquens; ne aut exterioribus deditus ab intimis corruat, aut solis interioribus occupatus, quæ foris debet proximis non impendat.' Cracow cathedral possessed a large collection of Gregory the Great's writings already at the beginning of the twelfth century. The Regula is not mentioned explicitly in the oldest records, but it was probably published together with Dialogues, on this, see Marian Plezia, 'Księgozbiór katedry krakowskiej wedle inwentarza z r. 1110', in Silva rerum. Series nova, ed. Tadeusz Ulewicz, Cracow, 1981, pp. 16-29 (p. 25). But we know about at least two later manuscripts containing the Regula Krzysztof Ożóg, Kultura umysłowa w Krakowie w XIV wieku: Środowisko duchowieństwa świeckiego, Wrocław and Cracow, 1987, pp. 41, 107.

${ }^{46}$ On this type of stylization of episcopal military activities, see Jeffrey R. Webb, 'Representations of the Warrior-Bishop in Eleventh-Century Lotharingia', Early Medieval Europe, 24, 2016, 1, pp. 103-30. It is worth stressing that in Poland, in the same spirit, the military service of bishops for monarchs was justified; it ceased concurrently with fading away of the idea of uniform monarchy. In this context one can refer to the opinion of Czesław Deptuła, who stressed that the model of bishop supporting the ruler in forging of 'powerful Christian Poland' collapsed in the thirteenth century when the place of one monarch was occupied by many competing feudal fragmentation dukes. See Czesław Deptuła, 'Biskup i władca: Z problematyki ideologii państwowej i świadomości narodowej polskiego średniowiecza', Więź, 11, 1968, pp. 42-65 (p. 52).

${ }^{47}$ At the same time it should be stressed that it is not possible to use a simple categorization of representatives of Polish episcopate to supporters of reform and its opponents, as was indicated by Marek Szymaniak, Biskup płocki Gedko (1206-1223): Działalność kościelno- polityczna na tle procesu emancypacji Kościoła polskiego spod władzy ksiażęcej, Toruń, 2007. 
of their position. One should assume that the collapse in the first half of the thirteenth century of the traditional vision of the episcopal position as a result, on the one hand, of including bishops in the centralistic policy of the papacy, and, on the other, of the devaluation of ducal power in the ecclesiastical sphere and the weakening of the tradition of public duties of bishops, had a significant impact on the shape of episcopal military prerogatives. The major dilemma in evaluating this problem is the insufficient source evidence mentioning military activity of bishops between the third and the eighth decades of the thirteenth century. Obviously, the silence of sources does not have to mean that such activity completely disappeared. Maybe it was just by accident that no information which would present bishops in traditional role of defenders of communities in face of repeated Mongol attacks and then numerous attacks by Jatvingians and Lithuanians has reached us. On the other hand, it seems very unlikely, because we have at our disposal much more extensive and diversified sources for this period than for the earlier one. They allow us at least to formulate the suspicion that bishops' military prerogatives partly lost their legitimate character at that time due to two phenomena which are clearly presented in the sources: bishops' withdrawal from ducal service and their obtaining of exemptions regarding the making contribution to the military potential of the state. Such an interpretation seems possible and even probable in the context of the noticed increase of the political significance of the Polish episcopate in the thirteenth century, because it should be noted that in the new conditions, the possibilities of permitted use of military means by bishops were very limited. Evaluating this matter, one should particularly notice that there are no sufficient traces that the model of such activity, which found sufficient justification only in secular competences of bishops or in feudal service to ruler, as it happened in the Empire or England, even in Hungary and to a certain extent also in Bohemia, could take root earlier in Poland. Therefore, one may suspect that together with the cessation of the traditional ducal sovereignty over the Church, it was more difficult for bishops to pursue their military ambitions, since in the changed situation, it was mainly such areas of activity that were left to them, which did not generate sufficient ideological justification for using military means, such as the struggle in the interest of their secular position and temporal power against dukes. And such forms of activity were never appreciated in the context of canon law or preferred within the ideals of episcopal power. There was no room either for such norms in the local ideal of episcopal ministry taking shape at that time. It is true that according to this ideal, a bishop should be a brave defender of rights, landed properties and freedom of the Church, but he should carry out this defence mostly with the 
help of spiritual and not material weapons. ${ }^{48}$ Such a hierarch was supposed to oppose violence using ecclesiastical means, and if they proved to be insufficient he was supposed to call on secular arm for help, and not expose himself to unnecessary danger. ${ }^{49}$ So it is no wonder that dukes were perceived as privileged holders of the secular sword, which they were supposed to use also in the interest of the Church and religion. ${ }^{50}$ It should also be highlighted that the defence of church goods and properties was something different, especially when bishops aimed at exclusive control over them, from the defence of the Church in the spirit described by earlier authors, who had stressed bishops' responsibility for safety of the community of the faithful within the integral Piast dominion.

A good example proving that bishops did not manage to work out regarding this ideal - sufficient legitimacy for their own military competences is the information describing conflicts of church hierarchs with Piast dukes. Although such conflicts had occurred regularly from the time of Henry Kietlicz, there is no trace in the sources until the eighth

${ }^{48}$ Mors et miracula beati Verneri, episcopi Plocensis auctore Iohanne, decano Plocensi, ed. Wojciech Kętrzyński, in MPH, vol. 4, Lwów, 1884, pp. 748-54, p. 750: Bishop Werner was killed 'pro deo et pro iusticia et pro defensione ecclesie'; Vita S. Stanislai episcopi Cracoviensis (Vita minor), ed. Wojciech Kętrzyński, in MPH, vol. 4, pp. 238-85 (pp. 262-65); Rocznik kapituły krakowskiej, in Najdawniejsze roczniki krakowskie i kalendarz, ed. Zofia Kozłowska-Budkowa, Warsaw, 1978, pp. 21-105, MPH s.n., vol. 5. Rocznik kapituły krakowskiej, p. 92 maintains that pious Prędota was 'verus procurator ecclesie' and 'sue ecclesie redditus, patrimonia et ceteras utilitates secundum equitatem eidem congruentes, libertatem clero omnimodam laycali et patrie liberacionem studiosissime procuravit'. According to II Catalogus episcoporum Wladislaviensium (Volboriensis), published by Wojciech Kętrzyński, in MPH, vol. 4, pp. 24-30 (p. 26); Bishop Wolimir was 'diligens possessionum ecclesie custos et vindex’; Janek of Czarnków calls his contemporary Bishop Dobiesław Sówka a 'virilis defensor bonorum et libertatis ecclesie', Joannis de Czarnkow Chronicon Polonorum, ed. Jan Szlachtowski, in MPH, vol. 2, Lwów, 1872, pp. 619-756 (p. 700). See also the opinion of Jan Długosz about certain bishops of Cracow: Katalogi biskupów krakowskich / Catalogi episcoporum Cracoviensis, ed. Józef Szymański, Warsaw, 1974, pp. 153 (Radost), 158 (Gedko), 170 (Wisław), 177 (Prędota), MPH s.n., vol. 10, part 2. Cf. Góra, 'Sylwetka biskupa', pp. 38 f., 90, 99 f., 161, 166.

${ }^{49}$ Rocznik kapituły gnieźnieńskiej, in Roczniki wielkopolskie, ed. Brygida Kürbis, Warsaw, 1962, pp.1-9 (pp. 7 f.), MPH s.n., vol. 6; Chronica Polonice maioris, ed. Brygida Kürbis, Warsaw, 1970, pp. 89 f., MPH s.n., vol. 8; Joannis de Czarnkow Chronicon Polonorum, pp. 691 f.; see also Stefan Kwiatkowski, Powstanie i kształtowanie się chrześcijańskiej mentalności religijnej w Polsce do końca XIII w., Warsaw, Poznań and Toruń, 1980, pp. 185 f.

${ }^{50}$ Traces of thirteenth-century dukes enforcing the ducals peace over bishops and diocesan clergy are very symptomatic. See Radosław Kotecki, 'Żydzi, świętokradcy i pokój książęcy: Wokół instytucji protekcji monarszej w Polsce piastowskiej', in Oryginalność $i$ wtórność polskiej kultury politycznej i religijnej od X do XIII wieku, ed. Roman Michałowski and Grzegorz Pac, Warsaw, 2020, pp. 27-75 (pp. 57-60). From the older literature, see especially Walenty Wójcik, 'Udzielanie pomocy monarszej Kościołowi w Polsce średniowiecznej’, Prawo Kanoniczne, 3, 1960, 1-2, pp. 71-86. 
decade of the thirteenth century that any bishop used armed force in these struggles. Here we have characteristic examples of two bishops of Wrocław, Laurence and Thomas I, who at the time of conflicts with subsequent Silesian Henrys and Bolesław Rogatka limited themselves to showing insubordination and a demanding attitude, and the most they could do was to use spiritual weapons against their secular lords and exert pressure backed by the solidarity of the rest of the episcopate. ${ }^{51}$ It is symptomatic that when Thomas II later decided to get involved in an open conflict with Henry IV, the historiography from that time did not mention any military means used by the bishop. Even the Chronica principum Polonioe, which presents this war in the broadest way, does not mention any armed actions by the bishop. Peter of Byczyna presented the bishop of Wrocław in the role of fugitive and the duke in the role of the conqueror seizing subsequent episcopal castles. This author had not noticed any confrontational situation even when the Duke Henry IV finally caught Bishop Thomas in the capital of the neighbouring duchy of Racibórz, where the bishop had found shelter. And there, near the city walls of Racibórz, the duke, apparently unexpectedly, gave in to the spiritual authority of the bishop and humbled himself before him. ${ }^{52}$

The general impression of this conflict cannot be substantially changed even by documentary sources and letters, even though they concurrently provide reasons to think that the course of events deviated from the scenario presented in the chronicle. We learn from them about armed resistance by the bishop's troops during the sieges of the castles, and about the presence of the hierarch himself in the most important episcopal castle in Otmuchów during its siege..$^{53}$ But it is worth noting that in order to oppose the duke, Thomas II used mercenaries in this war, and the related costs were so high that the soldiers' pay and the indemnities were not repaid until the end of bishop's life, that is within five years after the end of hostilities. ${ }^{54}$ But this was an effective solution, because although the bishop of

${ }^{51}$ Maciejewski, Episkopat polski, pp. 130 f.; Zbigniew Dalewski, 'Książę i biskup: Spór Bolesława Rogatki z biskupem wrocławskim Tomaszem I', RH, 73, 2007, pp. 83-106 (pp. 97-99).

${ }^{52}$ Chronica principum Polonice, ed. Zygmunt Węclewski, in MPH, vol. 3, Lwów, 1878, pp. 423-578 (p. 499).

${ }^{53}$ Schlesisches Urkundenbuch, 6 vols, Cologne, 1963-98, vol. 5: 1282-1290, 1993, ed. Heinrich Appelt, Josef Joachim Menzel and Winfried Irgang, no. 153.

${ }^{54}$ Schlesisches Urkundenbuch, vol. 6: 1291-1300, ed. Heinrich Appelt, Josef Joachim Menzel and Winfried Irgang, no. 47; Władysław Semkowicz, 'Nieznany testament biskupa wrocławskiego (1270-1292)', Collectanea Theologica, 17, 1936, 1-2, pp. 263-72 (pp. 266, 269 f.); Mateusz Goliński, ‘Służba rycerska a potencjał militarny księstw śląskich w późnym średniowieczu: Księstwo nysko-otmuchowskie’, Sobótka, 53, 1998, 1-2, pp.33-67 (p. 54). 
Wrocław was on the defensive, he managed to maintain resistance long enough not to lose this conflict in the end. We may even suspect that certain battles ended with the victory of the bishop's troops, since the Silesian bishop until his death in 1292 kept prisoners of war in captivity because he hoped to ransom them. ${ }^{55}$ Władysław Semkowicz even considered it possible that it was the force of the bishop's army gathered in Racibórz that convinced the duke of Wrocław to conclude a settlement. ${ }^{56}$ But one cannot agree with such a radical opinion, and the fact that the bishop hired mercenaries rather suggests that the normal forces of Bishop Thomas were weak and the possibilities for their mobilization insufficient. So we see that the thirteenth-century Polish bishop could carry out acts of war on his own account and use military means to accomplish ecclesiastical and political goals, but in practice his capabilities proved rather limited.$^{57}$ In this context, it is worth mentioning that in his official letters Bishop Thomas did not inform about the armed resistance and motivated his attempts to obtain secular help only by the ineffectiveness of the ecclesiastical censures imposed on the duke. ${ }^{58}$ One may suppose that bishop's resort to arms in this way was not a subject of common enthusiasm and the bishop of Wrocław preferred not to mention his accomplishments.

Another example of evaluation of military actions of church hierarchy, in this case clearly negative, were opinions about the bishop of Cracow, John Muskata. Against a few brief mentions on the waging of war by Muskata, or the omitting of his military activity by many episcopal catalogues and Jan Długosz, the message of the so-called Dominican edition of the Catalogi episcoporum Cracoviensium stands out. The author of this source, written down about the middle of the fifteenth century, but surely based on earlier texts, ${ }^{59}$ stated that John Muskata was dissolutus, which in this case probably means that he considered him a scoundrel

55 Schlesisches Urkundenbuch, vol. 6, no. 47.

${ }^{56}$ Semkowicz, 'Nieznany testament', p. 270.

${ }^{57}$ See symptomatic statement in Chronica principum Polonice, pp. 499 f.: ‘Et sicut a plerisque referentibus didici, Wratislaviam civitatem dedisset [Duke Henry IV - R.K., J.M.] episcopo et ecclesie si recipere voluisset, quam et episcopus recipere noluit, eo quod timeret, eam cum suo districtu et dominio defendere se non posse.'; Roman Grodecki, 'Dzieje polityczne Śląska do roku 1290', in Historia Śląska od najdawniejszych czasów do roku 1400, 3 vols, ed. Stanisław Kutrzeba, Cracow, 1933-36, vol. 1, pp. 155-326 (pp. 303-06).

${ }^{58}$ Recently Norbert Jerzak, 'Zabiegi biskupa Tomasza II o auxilium brachii secularis przeciw księciu Henrykowi IV Probusowi w 1287 roku', Wrocławski Przegląd Teologiczny, 24, 2016, 2, pp. 203-12.

${ }^{59}$ The editor of this source J. Szymański (Katalogi biskupów krakowskich, pp. 5 f.) was of the opinion that the whole family of catalogues of the bishops of Cracow, which includes catalogue $\mathrm{V}$, originates from the lost edition of catalogue $\mathrm{y}^{1}$. In our opinion visions describing Bishop Muskata must have been contained in this edition, since two 
who carelessly exceeded the norms of conduct ascribed to his social group. This author used the same term with respect to Bishop Paul of Przemyków, but justified it by citing a rape committed by the hierarch on a nun and other maidens, and detaining them at the bishop's court. ${ }^{60}$ So in this case translating the used word as dissolute seems to be the better choice. In the case of Muskata it is different, since the author referred to two visions which were supposed to justify the presented evaluation.

In the first of them, which was allegedly experienced by certain reliable man, the bishop's relative (sobrinus), the bishop of Cracow was presented as a bear knocking down a tree, which turned into a dragon and then into a rabid dog. ${ }^{61}$ The second vision occurred to a Franciscan monk called Mirosław, who saw Muskata in his dream as a bloodthirsty wolf in episcopal robes with crosier in his muzzle. On the shield next to it a sword covered in blood was shown and one could read: 'Predatory wolf! You took the sword out of the scabbard and bloodied it. The sword of revenge will pierce your soul'. ${ }^{62}$

In both visions we deal with the means of verbal and literary communication popular in the Middle Ages, that is by referring to metaphors taken from the real or invented world of animals in order to describe human activities and characters. ${ }^{63}$ At first glance we already see that the portrait of Bishop John Muskata was painted by using references to wild beasts, both real and those from the realm of imagination, which were often linked with figures of warriors. A bear mainly represents great strength, while also being one of the dangerous and wicked predators, whose figure personified, besides other vices, Violence and Anger. ${ }^{64}$

other catalogues from this group inform in almost identical words about the capture of the bishop by Duke Władysław because of the war, and one of them writing about the promiscuous nature of the bishop (dissolutus) mentions the visions but does not describe them, ibid., pp. 65, 114. Szymański also thought (ibid., pp. 77 f.) that it was a text of Dominican provenance, written down for use in schools, which however is currently questioned. Gerard Labuda, 'O katalogach biskupów krakowskich przed Długoszem', St.Źr., 27, 1983, pp. 83-96, connected this historical monument with the Cracovian cathedral chapter milieu and Długosz's work. Against connecting this catalogue with the Dominican convent in Cracow was also Wojciech Drelicharz, Annalistyka małopolska XIII-XV wieku: Kierunki rozwoju wielkich roczników kompilowanych, Cracow, 2003, pp. 148 f.

${ }^{60}$ Katalogi biskupów krakowskich, p. 99.

${ }^{61}$ Ibid., p. 101.

${ }^{62}$ Ibid., pp. 101 f.: 'Lupe rapax, Gladium evagisti, Insuper et cruentasti, Gladius vindex, Pretransibit animam tuam'.

${ }^{63}$ Natasha R. Hodgson, 'Lions, Tigers, and Bears: Encounters with Wild Animals and Bestial Imagery in the Context of Crusading to the Latin East', Viator, 44, 2013, 1, pp. 65-93 (p. 66).

${ }^{64}$ Ibid., pp. 73, 80, 92; Stanisław Kobielus, Bestiarium chrześcijańskie: Zwierzęta w symbolice i interpretacji: Starożytność i średniowiecze, Warsaw, 2002, p. 262. 
Dogs are not presented in a clear way in medieval art and literature. In the negative context, which is obvious in the text of interest here since we deal with a rabid dog, this animal was a dangerous beast and the attribute of personification of such human features like Exasperation and Hatred. ${ }^{65}$ In the Bible, a dog is usually mentioned in the bad or contemptuous sense describing bloodthirsty and immoral characters. ${ }^{66}$ The description of the bishop immediately brings to our mind the well-known opinion of Cistercian monk Caesarius of Heisterbach (1180-40), who in his two texts expressed his conviction that the German bishops of that time, who focused on worldly matters and conducted wars, would never enjoy salvation after death. ${ }^{67}$

The third creature appearing in the first vision is coluber, therefore a serpent, but our author translates it in vernacular language as dragon. This is not surprising since in the Bible these two terms are often synonyms. Symbolic meaning of both terms is also similar - in Christian texts they were often linked with Satan and his power. ${ }^{68}$ If we add that bear was also treated - in the negative contexts interesting for us - as a diabolic animal, being also a symbol of Satan, we will understand just how black, triply black, was image of Bishop John presented in the first vision of the discussed catalogue of the bishops of Cracow.

This apocalyptic image of the Bishop of Cracow is complemented by the aforementioned dream of Franciscan monk. It is a very blunt vision in the context of bishop's connections with warfare, because the main attribute of a warrior, that is the blooded sword, appears in it. This vision clearly refers to Biblical warnings not to spill human blood and not to fight with a sword.${ }^{69}$ But this is not all, since the martial activity of the bishop was characterized by referring to the topos of the wolf known from the Bible and medieval literature, which personified not only bravery, but also

${ }^{65}$ Kobielus, Bestiarium chrześcijańskie, p. 262.

${ }^{66}$ The Revelation places dogs together with people who will not get salvation. For more, see Hodgson, 'Lions, Tigers, and Bears', p. 80. Cf. also Dorothea Forstner, Świat symboliki chrześcijańskiej, transl. and ed. Wanda Zakrzewska, Paweł Pachciarek and Ryszard Turzyński, Warsaw, 1990, p. 293; Christine Edith Janotta, 'Der Hund im Mittelalter', Innsbrucker Historische Studien, 14-15, 1994, pp. 13-32 (pp. 31 f.).

${ }^{67}$ Victoria Smirnova, 'No Way to Salvation for German Bishops? The Case of St. Engelbert of Cologne', in Saintly Bishops and Bishop's Saints, ed. John S. Ott and Trpimir Vedriš, Zagreb, 2012, pp. 183-200 (pp. 183 f.). Also, see Wünsch, 'Der heilige Bischof', p. 277; Keupp, 'Die zwei Schwerter des Bischofs', pp. 5-8; Mesley, 'Beyond Celibacy', pp. 133 f.

${ }^{68}$ Forstner, Świat symboliki chrześcijańskiej, p. 307.

${ }^{69}$ Genesis 9.6; John 18.10-11; Matthew 26.52. On significance of these passages for the evaluation of bishops using arms and military means, see Keupp, 'Die zwei Schwerter des Bischofs', pp. 4 f.; Nakashian, Warrior Churchmen, pp. 30 f., 49, 71 f., 182 f. 
rapacity and cruelty. ${ }^{70}$ But certainly in this case it is more important that both wolf and bear are figures connected in the tradition of Christian imagery with violent bishops who did not observe their main duty, that is, the care of the flock entrusted to them, but in their vicious activity they turned against them like enemies. ${ }^{71}$

Therefore, the meaning of the analysed text is very strong. Bishop John was not only a dangerous man. ${ }^{72} \mathrm{He}$ was a diabolic beast, because war and violence were part of his nature. Thus this is the message that differs radically from the tale of Master Vincentius written approximately at the turn of the twelfth and thirteenth centuries about Bishop Alexander of Płock, who, although was a warrior and was compared like Muskata to a predatory animal, did not deserve condemnation because he was mainly involved in God's service and desired to accomplish glorious ideals. His wolfish nature occurred only in his conduct with pagans threatening Mazovia, so the martial character of the prelate was justified by a laudable desire to perform external duties for the benefit of community entrusted to his care. John Muskata's wars were of a different nature, and the author of the Catalogue was aware of it. His fault consisted in rebellion against Piast power, and at the same time using arms against his sheepfold, destroying churches, murders and thefts that would fit a degenerate criminal. Therefore the opinion of the author of the Catalogue should be treated as expression of local tradition defining the proper and non-proper norms of bishops' military activity through the prism of category of pastoral and public responsibility and motivated by the warrior's violent secular temper. ${ }^{73}$

${ }^{70}$ Kotecki, 'Aleksander z Malonne', pp. 67 f. Cf. Malcolm Drew Donalson, The History of the Wolf in Western Civilization: From Antiquity to the Middle Ages, Lewiston, NY, 2006; Aleksander Pluskowski, Wolves and the Wilderness in the Middle Ages, Woodbridge, 2006; Forstner, Świat symboliki chrześcijańskiej, pp. 308 f.

${ }^{71}$ For example Katarzyna Gołąbek, 'Antywzorzec biskupa w instrukcji kapituły krakowskiej na synod piotrkowski 1551 r.', PH, 101, 2010, 1, pp. 13-52 (p. 44).

${ }^{72}$ Comp. Sławomir Gawlas, 'Człowiek uwikłany w wielkie procesy - przykład Muskaty', in Człowiek w społeczeństwie średniowiecznym, ed. Roman Michałowski and Ewa Biernacka, Warsaw, 1997, pp. 391-401 (p. 393).

${ }^{73}$ The topos of a wolf in the context of political and maybe also armed activities, of the bishop of Cracow appeared for the first time already in Boniface's VIII bull of October 1301, where the pope, writing to his legate Mikołaj Boccasini, considered the bishop's activity not to be pastoral service but a 'wolf's audacity'. See Vetera monumenta Polonice et Lithuanice gentiumque finitimarum historiam illustrantia, 4 vols, ed. August Theiner, Rome, 1860-64, vol. 1, pp. 113 f. (no. 199): 'Ad audientiam nostram pervenit, quod Venerabilis frater noster Cracoviensis Episcopus, si venerabilis dici debeat, non attendens, quam sint periculose discordie, quam abhominanda discrimina, mala, dampna et pericula animarum, corporum atque rerum, que in Regno Ungarie temporibus istis invaluisse noscuntur, illa iuxta officii sui debitum minime impendit, sed quod 
The same author also very critically evaluated one of Muskata's predecessors from the second half of the thirteenth century. This second anti-model of a bishop was Paul of Przemyków (1267-94), who is here accused of alleged sexual excesses, which is, according to recent research, probably a part of a black legend developed by the court of Leszek Black and spread by the Dominicans, the leading motif of which was the alleged alliance of Bishop Paul with Lithuanians and provoking their invasion of Lesser Poland. ${ }^{74}$ Jan Długosz added gossip about hierarch's fascination with hunting as entertainment (bishops were allowed to hunt only to improve their health and fitness), ${ }^{75}$ which soon resulted in death - killing in anger ${ }^{76}$ one of the episcopal gamekeepers, who startled and alerted an animal. ${ }^{77}$ Unfortunately, this piece of information

deterius est, in sue salutis dispendium et dampnum irreparabile aliorum ea suscitare, fovere et nutrire presumit, licet hoc non pastoris oficium, sed lupi temeritas dinoscatur.'; Władysław Abraham, 'Sprawa Muskaty', RWHF PAU, 30, 1894, pp. 122-80 (p. 134).

74 Jan Gawron, 'Czarna legenda biskupa krakowskiego Pawła z Przemankowa', Annales Universitatis Marice Curie-Skłodowska. Sectio F, Historia, 71, 2016, pp. 25-64.

${ }^{75}$ John Langton, 'English Bishops' Hunting Rights, Hunts, and Hunting Grounds', in Princes of the Church: Bishops and Their Palaces, ed. David W. Rollason, London and New York, 2017, pp. 115-26 (p.115).

${ }^{76}$ In this context it is probably important that homicide committed by a clergyman as a crime of passion was considered in canonical tradition as disqualifying such clergyman to perform spiritual service till the end of his life. Comp. Atria A. Larson, 'Killing a Career: Homicide and the Development of Medieval Clerical Discipline', The Jurist: Studies in Church Law and Ministry, 74, 2014, 2, pp. 265-88.

${ }^{77}$ Jan Długosz, Catalogus Episcoporum Cracoviensium, in Joannis Dlugossii senioris canonici cracoviensis Opera omnia, 14 vols, ed. Ignacy Polkowski and Żegota Pauli, Cracow, 1863-87, vol.1, 1887, pp. 379-437, pp. 405 f.: 'Hic [Bishop Paul - R.K., J.M.] in tantam venationis fervore ferebatur erupisse insaniam, ut conditionis pontificalis oblitus, tractando in Kyelcensi districtu venationes, venatorem, qui feram incautus, ne usque ad casses delaberetur, dispulerat, lancea manu gestata indignabundus perfoderet, non veritus hominem pro bestia perdere, quem Unigenitus redemit sanguine suo.' Also in Joannis Dlugossii Annales seu Cronice incliti Regni Polonice, Books 7-8, ed. Zofia Budkowa et al., Warsaw, 1975, pp. 181 f. Gawron ('Czarna legenda', pp. 53 f.) connects this information with Długosz's unfriendly attitude toward hunting enthusiasts. But it is also possible that the chronicler derived this opinion from another source, since the hostile attitude toward clergymen enjoying this entertainment was widely spread, contrary to, as it seems, practice. Hunting entertainment was popular among the medieval episcopate in the whole of Europe, and the Cracovian canon knew that it had supporters also among Polish bishops. He recorded the death of the archbishop of Gniezno, Nicholas of Kurów during a hunt: Catalogus archiepiscoporum Gnesnensium, in Joannis Dlugossii senioris canonici cracoviensis Opera omnia, vol. 1, pp. 337-78 (p. 368). About this practice Ewa Wółkiewicz, 'Niegodna rozrywka czy instrument władzy? Biskupi i łowy w późnym średniowieczu', in Rzeczy i ludzie: Kultura materialna w późnym średniowieczu i w okresie nowożytnym: Studia dedykowane Marii Dąbrowskiej, ed. Wojciech Bis and Magdalena Bis, Warsaw, 2014, pp. 205-17. For more about criticism of hunting and clerical hunters, see Thomas Szabó, 'Die Kritik der Jagd: Von der Antike zum Mittelalter', in Jagd und höfische 
cannot be verified, but something else is interesting here. A substantial part of accusations against Bishop Paul, particularly by Długosz, refers to the canon of entertainment and activities characteristic for a group of warriors, who demonstrate and cultivate their masculine ethos through sexual activity, participation in hunts, violent temper or spending time together. ${ }^{78}$ Therefore, the bishop's opponents disseminated stories about him, which discredited him in the eyes of contemporaries, showing that he was responsible for acts which might be proper for laymen but were contrary to the norms preferred according to the ideals of episcopal ministry. These included the model of a bishop shown in the lives of St Stanislaus, the hero who as a pious man avoids contacts with the king and his court, and during feasts does not drink alcohol and does not spend long hours with his guests. ${ }^{79}$ It is significant that very similar accusations were brought in the files of canon law trials against John Muskata. ${ }^{80}$ It is not accidental that we also learn from the witnesses that such a vile way of living resulted in the fact that the bishop of Cracow neglected his episcopal and priestly duties. ${ }^{81}$

Kultur im Mittelalter, ed. Werner Rösener, Göttingen, 1997, pp. 167-229; Hubertus Lutterbach, 'Die für Kleriker bestimmten Verbote des Waffentragens, des Jagens sowie der Vogel- und Hundehaltung (a.500-900)', Zeitschrift für Kirchengeschichte, 109, 1998, 2, pp. 149-66; Hannele Klemettilä, Animals and Hunters in the Late Middle Ages: Evidence from the BnF MS fr. 616 of the 'Livre de chasse by Gaston Fébus', New York, 2015, pp. 196-98.

${ }^{78}$ Compare disscussion in Andrew G. Miller, 'Knights, Bishops and Deer Parks: Episcopal Identity, Emasculation and Clerical Space in Medieval England', in Negotiating Clerical Identities, pp. 204-37; idem, 'Deer Parks and Masculine Egos: Knights, Priors, and Bishops in the Medieval North of England', in Princes of the Church, pp. 127-41.

${ }^{79}$ Vita S. Stanislai episcopi Cracoviensis (Vita minor), pp. 257 f.; Vita S. Stanislai episcopi Cracoviensis (Vita maior), ed. Wojciech Kętrzyński, in MPH, vol. 4, pp. 319-438 (pp. 371 f.). Like participation in hunts, excessive feasts and drinking alcohol were considered conduct unbecoming the clergy. See Robert Bubczyk, 'Postawy ludzi Kościoła wobec alkoholu w średniowiecznej Polsce', in Oblicza alkoholu w kulturze elit od średniowiecza do współczesności, ed. Robert Bubczyk, Barbara Hołub and Justyna Sołtys, Lublin, 2015, pp. 49-63, where examples of imputing clergymen infatuation with alcohol are also presented, which reflect the cultural function of alcohol in the ecclesiastical milieu. About these ideals, see also Katherine Harvey, 'Food, Drink, and the Bishop in Medieval England, ca. 1100-ca. 1300', Viator, 46, 2015, 2, pp. 155-76.

${ }^{80}$ Analecta Vaticana 1202-1366, ed. Jan Ptaśnik, Cracow, 1915, pp. 80 f., 91-93 (no. 121: Acta inquisitionis Iacobi, archiepiscopi Gneznensis, contra Iohannem Muscata, episcopum Cracoviensem), Monumenta Poloniæ Vaticana, vol. 3; Tomasz Pietras, 'Krwawy wilk z pastorałem': Biskup krakowski Jan zwany Muskata, Warsaw, 2001, p. 215; Jacek Maciejewski, 'Making War and Enormities: Violence within the Church in the Diocese of Cracow at the Beginning of the 14th Century', in Ecclesia et Violentia: Violence against the Church and Violence within the Church in the Middle Ages, ed. Radosław Kotecki and Jacek Maciejewski, Newcastle upon Tyne, 2014, pp. 141-65 (pp. 152 f., 155 f., 163).

${ }^{81}$ Acta inquisitionis Iacobi, pp. 84, 88, 91 f.; Pietras, 'Krwawy wilk z pastorałem', p. 139; Maciejewski, Episkopat polski, pp. 212 f.; idem, 'Making War', pp. 158 f. 
It is worth noting that other sources, including some more contemporary to the person in question, present Paul of Przemyków as a clergyman respected by the papal legate,$^{82}$ or as a hierarch of great charisma, whose prayer had great intercessory power. ${ }^{83}$ John Muskata did not get such positive opinions in medieval historiography, although his activity could have been easily justified as royal service. The problem consists in the fact that his political opponents had their own optics of perceiving the conflicts of that time, and in the light of the fiasco of the bishop's political plans, they fully shaped memory about him, indicating him as an anti-model of a bishop, or, at the best, dooming his activity, also that beneficial for the Church of Cracow, to oblivion. And certainly it is no accident that Muskata's waging war is mentioned in a Franciscan annals from the beginning of the fourteenth century, the source genetically connected with the modelling by Władysław the Elbow's court a new approach to Polish history after the period of fragmentation. ${ }^{84}$ The Piast monarchy, which was in the process of rebuiltment, did not intend to tolerate activities against the majesty of the new rulers. So there was no room in the reborn kingdom for such bishops as Muskata.

After the period of fragmentation, relations between the nationwide ruler and episcopate had to be organized in a new way. They were characterized by pragmatism and a spirit of cooperation, which resulted from the slowly increasing impact of the royal court on appointing to the position of bishop, and rare conflicts did not take the form of armed confrontations. Unfortunately, very little is known about the Polish episcopate's engagement in the military sphere at the time of the last two Piast kings. But there is no doubt that military competences of bishops of that time were not exposed, and their help provided to monarchs was usually limited to advice, and financial and religious support, with a clear separation from personal engaging in warfare. ${ }^{85}$ But this does not

${ }^{82}$ Rocznik kapituły krakowskiej, p. 95; Gawron, 'Czarna legenda', p. 54.

${ }^{83}$ Vita et miracula sanctce Kyngce ducissce Cracoviensis, ed. Wojciech Kętrzyński, in MPH, vol. 4, pp. 662-744 (p. 708); Barbara Kowalska, 'Biskup w oczach hagiografów', Prace Naukowe Akademii im. Jana Długosza w Częstochowie. Zeszyty Historyczne, 13, 2014, pp. 13-29 (pp.15 f.).

${ }^{84}$ Rocznik małopolski, ed. August Bielowski, in MPH, vol. 3, pp. 135-202, p. 188: 'Item Johannes episcopus capitur a duce propter gwerras quas faciebat.' On the dating and provenance of this source, see Drelicharz, 'Annalistyka małopolska', p. 453; Jacek Banaszkiewicz, 'Rocznik tzw. małopolski (minorycki) z początku XIV wieku próba dookreślenia zabytku', in Przeszłość w kulturze średniowiecznej Polski, 2 vols, Warsaw, 2018, vol. 1, ed. Jacek Banaszkiewicz, Andrzej Dąbrówka and Piotr Węcowski, pp. 353-65 (pp. 353 f., 364 f.).

${ }^{85}$ For more on this issue, see Jacek Maciejewski, 'Biskupi polscy na wojnach monarchów w XIII-XIV wieku', Res Historica, 51, 2021 (in print). 
mean that Polish bishops completely lost their abilities as military leaders, so well-known from the time preceding the middle of the thirteenth century. Information about bold activities of a martial nature, violent actions or love of entertainments such as hunts, typical for community of warriors, did not disappear completely from the sources, thus reflecting a some kind of continuity of episcopal formation in the changing social and political conditions.

This may be illustrated in a rather specific way by two examples, which we will present at the end of our reflections, and which relate to a slightly later period. Let us begin with Jan Długosz's account about the incursion by the bishop of Poznan, Andrzej of Bnin (1438-79) of the town of Zbąszyń. This chronicler was a firm opponent of personal involvement of clergymen in fighting, ${ }^{86}$ but he was of the opinion that the Church had an important role to play during armed conflicts and did not avoid military rhetoric when narrating its history and the accomplishments of the saints.$^{87}$ Długosz described the siege of Zbąszyn not only in the Annales, but also in his Vitce episcoporum Posnaniensium, where we find an even more detailed description of events. ${ }^{88}$ The Cracovian canon tells about the armed expedition, which Bishop Andrzej undertook together with his brother Piotr, the castellan of Gniezno. They were supposed to bring 900 horsemen to the vicinity of Zbąszyń, and the goal of the expedition was to seize Hussite priests, who were very active in this Greater Poland town. Since the town did not want to let the bishop in, a siege was launched which lasted very long, until five Hussite priests, who were still in the town, were handed over to the bishop, who caused them to be publicly condemned and burned. ${ }^{89}$ Interestingly, Długosz dedicated the aforementioned Poznan catalogue to Andrzej of Bnin, so we may assume that the accounts regarding this prelate were carefully selected in this work. But description of this episode is not surprising, because the chronicler did not hide his hostility towards the Hussite movement and was very critical about it, accusing it of destroying the formerly flourishing Bohemian kingdom. ${ }^{90}$

${ }^{86}$ Joannis Dlugossii Annales seu Cronicoe incliti Regni Polonice, Book 7, p. 28.

${ }^{87}$ Urszula Borkowska, Treści ideowe $w$ dziełach Jana Długosza: Kościół i świat poza Kościołem, Lublin, 1983, pp. 34 f., 76, 144.

${ }^{88}$ Joannis Dlugossii Annales seu Cronicoe incliti Regni Polonice, Books 11-12, ed. Krzysztof Baczkowski et al., Warsaw, 2001, p. 206; Jan Długosz, Vita episcoporum Polonice, in Joannis Dlugossii senioris canonici cracoviensis Opera omnia, vol. 1, pp. $511 \mathrm{f}$.

${ }^{89}$ For more on this case, see Józef Nowacki, 'Biskup Andrzej Bniński w walce z husytami Zbąszynia: Nieznane karty procesów husyckich z roku 1439', RH, 10, 1934, 2, pp. 248-78; Paweł Kras, Husyci w piętnastowiecznej Polsce, Lublin, 1998, pp. 121-29, 252-57.

${ }^{90}$ Borkowska, Treści ideowe, pp. 145-70. 
The second narrative relates to a slightly earlier time of the archbishop of Gniezno, Bodzęta (1382-88), an active politician during the interregnum in 1382-84. A certain tiny chronicle from the first half of the fifteenth century, ${ }^{91}$ whose author described, among other things, the civil war in Greater Poland after death of King Louis the Great, narrated the war in which Archbishop Bodzęta also got involved. This prelate apparently allowed one of the sides of conflict to administer some church properties who as it turned out used them as a starting point to invade the land of their enemies, which, in turn, caused their desolation..$^{92}$ But the aforementioned chronicler thought fit to mention on this occasion that the metropolitan 'fought and took arms' ('pugnabat atque arma sumpserat') against the Kalisz Judge Nicholas of Wenecja. ${ }^{93}$ Alas, we do not know any details about these military clashes. Bodzęta did not come from a wealthy family, so he probably did not use private troops, but stating whether he hired mercenaries or conducted warfare based on his servant knights and people settled on church properties would be sheer guesswork. Even if we reject the suggestion, which comes to mind after reading the aforementioned source, that the metropolitan personally used a sword, there is no doubt that the archbishop was at least the organizer of armed enterprises aimed at defence of ecclesiastical properties. ${ }^{94}$

The above examples clearly show that clergymen narrating on bishops engaging in military violence wrote more openly when a clear justification in the norms of canon law could be found for such actions. In the case of Archbishop Bodzęta, the aim was to defend stolen church properties and the archbishop's attack on Zbąszyń was motivated by the intent to combat

${ }^{91}$ For more about the source, see Krzysztof Ożóg, 'Dopełnienie szamotulskie studium źródłoznawcze', SH, 35, 1992, 2, pp. 143-53.

${ }^{22}$ Jan Tęgowski, 'Postawa polityczna arcybiskupa gnieźnieńskiego Bodzęty w czasie bezkrólewia po śmierci Ludwika Węgierskiego', in Genealogia - rola związków rodzinnych i rodowych w życiu publicznym $w$ Polsce średniowiecznej na tle porównawczym, ed. Andrzej Radzimiński and Jan Wroniszewski, Toruń, 1996, pp. 131-43 (pp. 138 f.).

${ }^{93}$ Dopetnienie szamotulskie, ed. August Bielowski, in MPH, vol. 2, pp. 861-71, p. 861: 'Sed et Bodzanta archiepiscopus Gneznensis pugnabat atque arma sumpserat contra nobilem Nicolaum heredem de Veneciis, iudicem maioris Polonie generalem, per quod omnes ville archiepiscopales in districtu Znenensi fuerunt per ignem penitus desertate.' Compare Jan Pakulski, 'Mikołaj z Wenecji - krwawy diabeł: Ze studiów nad genealogią Nałęczów', Prace Komisji Historii Bydgoskiego Towarzystwa Naukowego, 7, 1970, pp. 53-61 (p. 56).

${ }^{94}$ The use of arms and warriors by Bodzęta to achieve political goals is also confirmed by his contemporary commentator of political life, Jan of Czarnków. He described how the archbishop arrived in Cracow with 500 spearmen being in the service of Mazovian Duke Siemowit IV, one of the candidates for the Polish crown. No armed incidents happened then, but who knows what could have happened if the Bodzęta's troop had been allowed to enter the town, since the action was allegedly aimed at kidnapping one of Louis's daughters, Hedvig. Joannis de Czarnkow Chronicon Polonorum, p. 737. 
those who had rebelled against the Church. Thus, both cases fit well the views of popes and canonists, which contributed to a significant relaxation of the initial bans on the personal participation of bishops in wars.

V.

The problems analysed in this article, relating to the military activity of the Polish episcopate, cannot be described in absolute and unequivocal categories, mainly due to the brevity, accidental character and fragmentary nature of the sources. We may assume that the evidence at our disposal shows only a small portion of a more colourful reality and more complicated relations of bishops with the military sphere and, perhaps, of a more complex perception of this problem. Nevertheless, assumption that in the Piast era the phenomenon of the 'warrior-bishop' was the constant attention-focusing element of social life raises doubts, since in Poland relations between the episcopate and warfare were never as strong as in other monarchies of Latin Europe, such as the Holy Roman Empire, Spain, England or countries geographically closer to Poland, such as Denmark and Hungary. This does not, however, mean that in the Piast domain there were no bishops actively, or even personally engaging in fightings. But it makes one consider why authors of that time, who were churchmen themselves, told us so little about those issues. The simplest explanation which comes to mind is their lack of interest in bishops' military activity, but also in the legal and ethical context of this phenomenon, which could, to a certain extent, result from the intellectual weakness of Polish cathedral milieux of the thirteenth and fourteenth centuries. Until the fifteenth century, the elites of the Polish Church had not shown any deeper doctrinal, theological or legal interests, especially such that would have manifested itself in the processes of creative reflection, and not only in the passive acceptance of patterns and prescriptions coming from abroad..$^{95}$ The exceptional example of Vincentius's narrative devoted to the bishops of Płock shows best that a successful attempt to describe the armed achievements of church hierarchs required highly advanced writing skills and a rich intellectual background. But even Vincentius's accounts did not raise interest among the later authors, who simply omitted it in their travesties of Vincentius's chronicle. It was only mentioned by Jan Długosz, who, incidentally, had difficulties with understanding the text of the chronicle. ${ }^{96}$ Jan of Dąbrówka

${ }^{95}$ Szymański, 'Biskupstwa polskie’, pp. 146-51.

${ }^{96}$ Joannis Dlugossii Annales seu Cronica incliti Regni Polonice, Books 3-4, ed. Zofia Budkowa et al., Warsaw, 1970, p. 312. 
had better intuition; it is interesting that contrary to his namesake he was not afraid to define Alexander's activities explicitly as fortitudinis corporalis exercitio and manualis fortitudo. ${ }^{97}$ But he did not consider the martial achievements of the bishop from the point of view of their legality, either, and was satisfied to repeat Vincentius's statement that Simon's spiritual struggle was more laudable than the physical fight of Bishop Alexander. ${ }^{98}$ It is enough to say in this context that only in the fifteenth century the need to justify conducting wars against the Teutonic Order forced Polish intellectuals to show an interest in the idea of the just war. ${ }^{99}$

In spite of the modest sources available to us, we nevertheless have access to certain aspects of the given issue. The problem of bishops' recourse to weapons is described more clearly. None of the sources, except for an unclear message of the Dopetnienie szamotulskie, mentions that bishops personally participated in fights or used arms. The use of arms by the bishop is only mentioned in Długosz's story about Bishop Paul of Przemyków, but it relates to the hunting and not to warfare, and the story itself is a derivative of a misleading legend slandering the bishop. This provides a basis for assuming that the Polish church milieu was at least aware of the ban on using arms by clergymen, which is explicitly suggested in the chronicles of Gallus and Vincentius. Of course it is not possible to state on this basis whether these norms were commonly observed; anyway, Polish church law, except for the statute in the collection of Legate Philip of Fermo (1279), possibly even unrelated to Polish reality, omitted that matter as if it did not exist. ${ }^{100}$ But it is worth mentioning that the oldest Polish customary law suggests adoption of such norms; in its preserved form reflecting late thirteenth-century reality it included bishops and priests (polensche bischoffe unde pfaffen) in the category of people who were forbidden personally to participate in the court duels, that is fights with clubs, but they had a possibility of putting up substitutes - pugils. ${ }^{101}$ In this case it is

${ }^{97}$ Jan z Dąbrówki, Komentarz do Kroniki Polskiej Mistrza Wincentego zwanego Kadłubkiem, ed. Marian Zwiercan, Cracow, 2008, pp. 132-37, MPH s.n, vol. 14.

${ }^{98}$ Ibid., p. 136: 'Merito, quia plus valet apud Deum devota oracio quam corporalis fortitudo'.

${ }^{99}$ Ludwik Ehrlich, Polski wykład prawa wojny XV wieku: Kazanie Stanisława ze Skarbimierza 'De bellis iustis', Warsaw, 1955, pp. 98-101.

100 Such a ban is defined in one of the statutes of collection issued by Legate Philip at the synod in Buda respectively for Poland and Hungary. Its content, particularly focused on bishops' involvement in conspiracies, thefts and arsons, seem nevertheless to correspond better with the Hungarian reality of the second half of the thirteenth century than with the Polish one. See Antiquissimce constitutiones synodales provincioe Gneznensis, ed. Romuald Hube, St Petersburg, 1856, pp. $77 \mathrm{f}$.

${ }^{101}$ Najstarszy zwód prawa polskiego, ed. Józef Matuszewski and Jacek S. Matuszewski, Łódź, 1995, p. 211 (c. 23,15). 
obvious that we deal with the local custom founded on the canonical ban on the use of weapons by clergymen, the beginning of which we may find in the twelfth century, that is, before the reforms of Henry Kietlicz. ${ }^{102}$

However, Polish sources, similarly to all European source evidence clearly distinguish the problem of personal use of arms from other forms of bishops' participation in warfare, which may suggest that also in Poland bishops had a number of possibilities for conducting military activity regardless of the canonical ban on direct contact with weapons. The analysed records of bishops' military activity can be divided into two categories. The first of these does not see anything wrong in such activity, whereas includes accounts that castigate bishops for using military force. And this very distinction can be considered as very symptomatic for medieval legal and literary texts, in which military episcopal activity was described not from the point of view of its character and the nature of military means used, but in terms of the intentions behind bishops' actions. ${ }^{103}$ So Polish sources consider as proper actions only those that fulfil pious goals: the defence of the Church, the religious and political community, the doctrine of faith, or maintaining the integrity of church properties, whereas those which do not fit this model are those bringing harm to the Church or negatively affecting the political community and its legal secular ruler.

It is, however, obvious that the same ideas which influenced the content and purport of available sources also influenced their heroes, although the scope of this is unknown due to the shortage of sources other than narrative ones, especially those which would present a different perspective, that is legal and documentary sources. Nevertheless, we may con-

${ }^{102}$ The trace of applying such a norm is (as discovered by W. Holtzmann) the response of Celestine III dated 1193 to the letter of the bishop of Cracow, in which the pope explained what should be done with a clergyman who put up a substitute to the court duel, and this substitute killed the opponent in the fight. The pope stated that putting up substitutes for court duels by bishops took place in Poland secundum prauam consuetidinem terre. See Adam Vetulani, 'W poszukiwaniu nowych źródeł', in idem, Z badań nad kultura prawnicza, pp.75-94, text of the bull at pp. $83 \mathrm{f}$. It is worth mentioning that also a Bohemian source from that time, the statutes of Duke Conrad Otto (1189), exclude clergymen from the customary law, including the duty of participation in court duels called club (kiy), due to the consent of the prince regarding the clergy's observance of canon law: 'In hiis omnibus excipimus privilegia religiosorum virorum a principibus eis concessa, et jura clericorum cum dotibus ecclesiarum, quibus reguntur secundum jus canonicum', Codex iuris Bohemici, 4 vols, ed. Hermenegild Jireček, Prague, 1867-83, vol. 1, p. 56 (c. 14) (text preserved in the confirmation charter of Přemysl Otakar I).

${ }^{103}$ For example, see Nakashian, Warrior Churchmen, particularly pp. 183, 203; Louisa Taylor, 'Bishops, War, and Canon Law: The Military Activities of Prelates in High Medieval Norway', Scandinavian Journal of History, 7, 2019, 2, pp. 1-23 (p. 13). 
clude that in the whole period of interest, the Polish ecclesiastical circles knew both ideological and legal norms, which - if properly applied enabled bishops to get involved in military matters and to wage wars. Until the middle of the thirteenth century the duty of securing the subordinated community against external threat was of great importance. It maintained its value as long as the Polish episcopate implemented its mission in compliance with the principles of the state church, observing traditional duties toward monarchy and its rulers. The importance of this norm radically weakened when the demand of church autonomy was realized. From that time onwards, the scope of possibilities of using military force by bishops was diminished, although probably certain legal possibilities still existed until the end of Piast era (and beyond), and bishops took advantage of them. What truly distinguishes Polish reality during the periods of disintegration and the re-united Kingdom from the situation occurring at that time in other monarchies, including the neighbouring ones, is the low degree of militarization of the episcopate. However, the main factor which led to such circumstances was not of a legal or ideological nature, as it was not the result of the introduction of reform ideals, but resulted from politico-organizational transformation. The collapse of the united monarchy advancing from the beginning of the thirteenth century and the consequent redefinition of bishops' position in the state seem to be of a crucial importance for these issues. Although these changes did not deprive bishops of military resources and prerogatives, they limited their development to such extent that even bishops' return to state service under the rule of the last Piast kings did not result in a noticeable increase of church hierarchs' interest in military matters.

(Translated by Elżbieta Petrajtis-O’Neill)

\section{Summary}

This article is an attempt to illustrate relations between the theory and practice of military activity of bishops in Poland in the Piast era (until 1370). The authors' interest is particularly focused on the imagined places of the military activity of diocesan bishops in the context of the ideal of episcopal power formulated in the Gniezno province and the ideological and legal patterns reaching these regions and regulating the possibilities of the use of weapons by the clergy. In particular the authors seek to establish more precisely the ways in which church hierarchs participated in wars and conducted them. An analysis of source evidence illustrating this problem, most of which has not been studied hitherto, allows one to 
notice correlation and discrepancies between the local situation and that occurring in other monarchies of Latin Christendom. Although the available sources treat as doubtful the option of the development in Poland of the 'warrior-bishop' phenomenon - well known in other regions of medieval Europe - as the constant and attention-focusing element of social life, it also shows that in the Piast domain the numerous forms of military activity, including active or even personal participation in warfare, were possible under certain conditions and were justified on legal and ideological grounds. What can be clearly noticed is the fact that Polish ecclesiastical circles were aware of the basic canonical ban on the personal use of arms by clergymen. But similarly to the whole European literature, Polish sources clearly distinguish the problem of personal use of weapons from other forms of episcopal participation in warfare, which may suggest that also in Poland bishops had several possibilities of conducting military activity regardless of the canonical ban on direct contact with arms. The analysed examples of bishops' military activity can be divided into two categories, the first of which does not see anything wrong in such activity, whereas in the second there are accounts condemning bishops for using military force. Such a distinction can be also considered as very characteristic for medieval literature, in which military activity was described not from the point of view of its character and nature of military means used, but of the intentions behind bishops' actions.

(Translated by Elżbieta Petrajtis-O’Neill)

\section{Bibliography}

Abraham, Władysław, 'Sprawa Muskaty', RWHF PAU, 30, 1894, pp. 122-80.

Ambler, Sophie T., Bishops in the Political Community of England, 1213-1272, Oxford: Oxford University Press, 2017.

Analecta Vaticana 1202-1366, ed. Jan Ptaśnik, Cracow: Akademia Umiejętności, 1915, Monumenta Poloniæ Vaticana, vol. 3.

Antiquissimce constitutiones synodales provincice Gneznensis, ed. Romuald Hube, St Petersburg: Typis II sectionis cancellariæ imperatoris, 1856.

Arnold, Benjamin, Count and Bishop in Medieval Germany, Philadelphia, PA: University of Pennsylvania Press,1991.

Arranz Guzmán, Ana, 'Cuando el clérigo va a la guerra: algunos ejemplos de obispos “peleadores”', in Guerra y paz en la Edad Media, ed. Ana Arranz Guzmán, María del Pilar Rábade Obradó and Óscar Villarroel Gonzáles, Madrid: Sílex, 2013, pp. 275-308.

Baldwin, John W., The Government of Philip Augustus: Foundations of French Royal Power in the Middle Ages, Berkeley, CA, and Ann Arbor, CA: University of California Press, 1986.

Banaszkiewicz,Jacek, 'Rocznik tzw. małopolski (minorycki) z początku XIV wieku próba dookreślenia zabytku', in Przeszłość w kulturze średniowiecznej Polski, 2 vols, 
Warsaw: Instytut Historii PAN and Neriton, 2018, vol. 1, ed. Jacek Banaszkiewicz, Andrzej Dąbrówka and Piotr Węcowski, pp. 353-65.

Baran-Kozłowski, Wojciech, Arcybiskup gnieźnieński Henryk Kietlicz (1199-1219):

Działalność kościelna i polityczna, Poznań: Wydawnictwo Poznańskie, 2005.

Baran-Kozłowski, Wojciech, 'Reforma gregoriańska w Europie Środkowej za pontyfikatu Innocentego III’, in Kościół w monarchiach Przemyślidów i Piastów, ed. Józef Dobosz, Poznań: Wydawnictwo Poznańskie, 2009, pp. 151-67.

Baran-Kozłowski, Wojciech, 'Rola Stolicy Apostolskiej w działaniach reformatorskich arcybiskupa Henryka Kietlicza', in Sacri canones servandi sunt: Ius canonicum et status ecclesice sæculis XIII-XV, ed. Pavel Krafl, Prague: Historický Ústav AV ČR, 2008, pp. 490-94.

Barrow, Julia, The Clergy in the Medieval World: Secular Clerics, Their Families and Careers in North-Western Europe, c. 800-c. 1200, Cambridge: Cambridge University Press, 2015.

Benson, Robert L., 'The Obligations of Bishops with "Regalia”: Canonistic Views from Gratian to the Early Thirteenth Century', in Proceedings of the Second International Congress of Medieval Canon Law, ed. Stephan Kuttner and Joseph Ryan, Vatican City: S. Congregatio de Seminariis et Studiorum Universitatibus, 1965, pp. 123-37.

Bielak, Włodzimierz, Biskup i jego urzad w oczach średniowiecznych kronikarzy polskich, Lublin: Wydawnictwo KUL, 2011.

Borkowska, Urszula, Treści ideowe $w$ dziełach Jana Długosza: Kościół i świat poza Kościołem, Lublin: Wydawnictwo KUL, 1983.

Boroń, Piotr, 'Biskup wrocławski Walter i początki kultury umysłowej na Śląsku', in Źródła kultury umysłowej w Europie Środkowej ze szczególnym uwzględnieniem Górnego Śląska, ed. Antoni Barciak, Katowice: Instytut Górnośląski, 2005, pp. 115-32.

Brundage, James A., 'Holy War and the Medieval Lawyers', in The Holy War, ed. Thomas Patrick Murphy, Columbus, OH: Ohio State University Press, 1976, pp. 99-140.

Bubczyk, Robert, 'Postawy ludzi Kościoła wobec alkoholu w średniowiecznej Polsce', in Oblicza alkoholu w kulturze elit od średniowiecza do współczesności, ed. Robert Bubczyk, Barbara Hołub and Justyna Sołtys, Lublin: Wydawnictwo UMCS, 2015, pp. 49-63.

Bührer-Thierry, Geneviève, 'Bishops as City Defenders in Early Medieval Gaul and Germany', in Between Sword and Prayer: Warfare and Medieval Clergy in Cultural Perspective, ed. Radosław Kotecki, Jacek Maciejewski and John S. Ott, Leiden and Boston, MA: Brill, 2018, pp. 24-45.

Bührer-Thierry, Geneviève, 'Des évêques sur la frontière: Christianisation et sociétés de frontière sur les marches du monde germanique aux $\mathrm{X}^{\mathrm{e}}-\mathrm{XI}^{\mathrm{e}}$ siècle', Quœestiones Medii Ævi Novœe, 16, 2011, pp. 61-80.

Burkhardt, Stefan, Mit Stab und Schwert: Bilder, Träger und Funktionen erzbischöflicher Herrschaft zur Zeit Kaiser Friedrich Barbarossas: Die Erzbistümer Köln und Mainz im Vergleich, Ostfildern: Thorbecke, 2008. 
Campbell, Gerard J., 'Temporal and Spiritual Regalia during the Reigns of St. Louis and Philip III', Traditio, 20, 1964, pp. 351-83.

Chapman, Alice, Sacred Authority and Temporal Power in the Writings of Bernard of Clairvaux, Turnhout: Brepols, 2013.

Chew, Helena M., The English Ecclesiastical Tenants in Chief and Knight Service, London: Oxford University Press, 1932.

Chronica Polonice maioris, ed. Brygida Kürbis, Warsaw: PWN, 1970, MPH s.n., vol. 8. Chronica principum Polonice, ed. Zygmunt Węclewski, in MPH, vol. 3, Lwów: Akademia Umiejętności, 1878, pp. 423-578.

Codex iuris Bohemici, 4 vols, ed. Hermenegild Jireček, Prague: [n. pub.], 1867-83, vol. 1.

Coupland, Simon, 'The Carolingian Army and the Struggle against the Vikings', Viator, 35, 2004, pp. 49-70.

Crosby, Everett U., The King's Bishops: The Politics of Patronage in England and Normandy, 1066-1216, New York: Palgrave Macmillan, 2013.

Cushing, Kathleen, Papacy and Law in the Gregorian Revolution: The Canonistic Work of Anselm of Lucca, Oxford: Clarendon Press, 1998.

Dalewski, Zbigniew, 'Książę i biskup: Spór Bolesława Rogatki z biskupem wrocławskim Tomaszem I', RH, 73, 2007, pp. 83-106.

Deptuła, Czesław, 'Biskup i władca. Z problematyki ideologii państwowej i świadomości narodowej polskiego średniowiecza', Więź, 11, 1968, pp. 42-65.

Derwich, Marek, 'Relacje między monarchią i możnymi a Kościołem, czy: kto, kiedy i gdzie fundował najstarsze instytucje kościelne w Polsce? [na marginesie monografii Józefa Dobosza, Monarchia i możni wobec Kościoła w Polsce do początku XIII wieku]', RH, 68, 2002, pp. 195-205.

Długosz, Jan, Catalogus Archiepiscoporum Gnesnensium, in Joannis Dlugossii senioris canonici cracoviensis Opera omnia, 14 vols, ed. Ignacy Polkowski and Żegota Pauli, Cracow: E Typographia ephemeridum 'Czas’ Fr. Kulczycki \& soc., 1863-87, vol. 1, 1887, pp. 337-78.

Długosz, Jan, Catalogus Episcoporum Cracoviensium, in Joannis Dlugossii senioris canonici cracoviensis Opera omnia, 14 vols, ed. Ignacy Polkowski and Żegota Pauli, Cracow: E Typographia ephemeridum 'Czas' Fr. Kulczycki \& soc., 1863-87, vol. 1, 1887, pp.379-437.

Dobosz, Józef, 'Arcybiskup Janik i jego następcy. Przygotowanie do reformy Henryka Kietlicza', in 1000 lat Archidiecezji Gnieźnieńskiej, ed. Jerzy Strzelczyk and Janusz E. Górny, Gniezno: Gaudentinum, 2000, pp. 81-96.

Donalson, Malcolm Drew, The History of the Wolf in Western Civilization: From Antiquity to the Middle Ages, Lewiston, NY: Edwin Mellen Press, 2006.

Dopetnienie szamotulskie, ed. August Bielowski, in MPH, vol. 2, Lwów: Akademia Umiejętności, 1872, pp. 861-71.

Drelicharz, Wojciech, Annalistyka małopolska XIII-XV wieku: Kierunki rozwoju wielkich roczników kompilowanych, Cracow: PAU, 2003.

Duggan, Lawrence G., Armsbearing and the Clergy in the History and Canon Law of Western Christianity, Woodbridge: Boydell Press, 2013. 
Duggan, Lawrence G., 'Armsbearing by the Clergy and the Fourth Lateran Council', in The Fourth Lateran Council and the Development of Canon Law and the 'ius commune', ed. Andrea Massironi and Atria A. Larson, Turnhout: Brepols, 2018, pp. 63-75.

Ehrlich, Ludwik, Polski wykład prawa wojny XV wieku: Kazanie Stanisława ze Skarbimierza 'De bellis iustis', Warsaw: Wydawnictwo Prawnicze, 1955.

Erdmann, Carl, The Origin of the Idea of Crusade, transl. Marshall W. Baldwin and Walter Goffart, Princeton, NJ: Princeton University Press, 1977.

Fletcher, Richard A., 'Regalian Right in Twelfth-Century Spain: The Case of Archbishop Martín of Santiago de Compostela', Journal of Ecclesiastical History, 28, 1977, 4, pp. 337-60.

Forstner, Dorothea, Świat symboliki chrześcijańskiej, transl. and ed. Wanda Zakrzewska, Paweł Pachciarek and Ryszard Turzyński, Warsaw: Pax, 1990.

Fried, Johannes, 'Der Regalienbegriff im 11. und 12. Jahrhundert, Deutsches Archiv für Erforschung des Mittelalters, 29, 1973, pp. 450-528.

Galli Anonymi Cronice et gesta ducum sive principium Polonorum, ed. Karol Maleczyński, Cracow: PAU, 1952, MPH s.n., vol. 2.

Gawlas, Sławomir, 'Człowiek uwikłany w wielkie procesy - przykład Muskaty', in Człowiek w społeczeństwie średniowiecznym, ed. Roman Michałowski and Ewa Biernacka, Warsaw: DiG, 1997, pp.391-401.

Gawron, Jan, 'Czarna legenda biskupa krakowskiego Pawła z Przemankowa', Annales Universitatis Marice Curie-Skłodowska. Sectio F, Historia, 71, 2016, pp. 25-64.

Goliński, Mateusz, 'Służba rycerska a potencjał militarny księstw śląskich w późnym średniowieczu: Księstwo nysko-otmuchowskie’, Sobótka, 53, 1998, 1-2, pp. 33-67.

Gołąbek, Katarzyna, 'Antywzorzec biskupa w instrukcji kapituły krakowskiej na synod piotrkowski 1551 r.', PH, 101, 2010, 1, pp. 13-52.

Góra, Jan W., 'Sylwetka biskupa w XII i XIII-wiecznej Polsce na podstawie kronik i żywotów świętych', Studia Teologiczno-Dogmatyczne, 4, 1984, pp. 3-191.

Gregorii Magni Liber regulce pastoralis, ed. Jacques-Paul Migne, in PL, t. 77, Paris: apud editorem Jacques-Paul Migne, 1849.

Grodecki, Roman, 'Dzieje polityczne Śląska do roku 1290', in Historia Śląska od najdawniejszych czasów do roku 1400, 3 vols, ed. Stanisław Kutrzeba, Cracow: PAU, 1933-36, vol. 1, pp. 155-326.

Güttner-Sporzyński, Darius von, Poland, Holy War, and the Piast Monarchy, 11001230, Turnhout: Brepols, 2014.

Harvey, Katherine, 'Food, Drink, and the Bishop in Medieval England, ca. 1100ca. 1300', Viator, 46, 2015, 2, pp. 155-76.

Hehl, Ernst-Dieter, Kirche und Krieg im 12. Jahrhundert: Studien zu Kanonischem Recht und politischer Wirklichkeit, Stuttgart: Hiersemann, 1980.

Hockay, Jean, 'Alexandre et Gauthier: Deux Malonnois en Pologne, au XII siècle', Guetteur Wallon, 54, 1978, 3, pp. 81-95.

Hodgson, Natasha R., 'Lions, Tigers, and Bears: Encounters with Wild Animals 
and Bestial Imagery in the Context of Crusading to the Latin East', Viator, 44, 2013, 1, pp. 65-93.

Houghton, Robert, 'Italian Bishops and Warfare during the Investiture Contest: The Case of Parma', in Between Sword and Prayer: Warfare and Medieval Clergy in Cultural Perspective, ed. Radosław Kotecki, Jacek Maciejewski and John S. Ott, Leiden and Boston, MA: Brill, 2018, pp. 274-302.

Howe, John, 'The Nobility's Reform of the Medieval Church', AHR, 93, 1988, 2, pp. 317-39.

Irgang, Winfried, “Libertas ecclesiæ" und landesherrliche Gewalt - Vergleich zwischen dem Reich und Polen', in Winfried Irgang, Schlesien im Mittelalter: Siedlung - Kirche - Urkunden: ausgewählte Aufsätze, ed. Norbert Kersken and Jürgen Warmbrunn, Marburg: Herder Institut, 2007, pp. 182-208.

Irgang, Winfried, “Libertas ecclesiæ” und landesherrliche Gewalt: Zur Kirchenpolitik der schlesischen Piasten im 13. Jahrhundert', in Winfried Irgang, Schlesien im Mittelalter: Siedlung - Kirche - Urkunden: ausgewählte Aufsätze, ed. Norbert Kersken and Jürgen Warmbrunn, Marburg: Herder Institut, 2007, pp. 158-81.

Jan z Dąbrówki, Komentarz do Kroniki Polskiej Mistrza Wincentego zwanego Kadłubkiem, ed. Marian Zwiercan, Cracow: PAU, 2008, MPH s.n., vol. 14.

Janotta, Christine Edith, 'Der Hund im Mittelalter', Innsbrucker Historische Studien, 14-15, 1994, pp. 13-32.

Jensen, Kurt Villads, 'Bishops on Crusades', in 'Dominus Episcopus': Medieval Bishops between Diocese and Court, ed. Anthony John Lappin and Elena Balzamo, Stockholm: Kungliga Vitterhets Historie och Antikvitets Akademien, 2018, pp. 83-99.

Jerzak, Norbert, 'Zabiegi biskupa Tomasza II o auxilium brachii secularis przeciw księciu Henrykowi IV Probusowi w 1287 roku', Wrocławski Przegląd Teologiczny, 24, 2016, 2, pp. 203-12.

Joannis de Czarnkow Chronicon Polonorum, ed. Jan Szlachtowski, in MPH, t. 2, Lwów: Akademia Umiejętności, 1872, pp. 619-756.

Joannis Dlugossii Annales seu Cronice incliti Regni Polonice, Books 3-4, ed. Zofia Budkowa et al., Warsaw: PWN, 1970.

Joannis Dlugossii Annales seu Cronicce incliti Regni Polonice, Books 7-8, ed. Zofia Budkowa et al., Warsaw: PWN, 1975.

Joannis Dlugossii Annales seu Cronicce incliti Regni Polonice, Books 11-12, ed. Krzysztof Baczkowski et al., Warsaw: PWN, 2001.

Katalogi biskupów krakowskich, ed. Józef Szymański, Warsaw: PWN, 1974, MPH s.n., vol. 10, part 2.

Kejř, Jiří, ‘Pronikání kanonického práva do středověkého českého státu', Revue církevního práva, 8, 1997,3, pp. 137-56.

Keupp, Jan U., 'Die zwei Schwerter des Bischofs: Von Kriegsherren und Seelenhirten im Reichsepiskopat der Stauferzeit', Zeitschrift für Kirchengeschichte, 117, 2006, pp.1-24. 
Klemettilä, Hannele, Animals and Hunters in the Late Middle Ages: Evidence from the BnF MS fr. 616 of the 'Livre de chasse by Gaston Fébus', New York: Routledge, 2015.

Kobielus, Stanisław, Bestiarium chrześcijańskie: Zwierzęta w symbolice i interpretacji: Starożytność i średniowiecze, Warsaw: Pax, 2002.

Kotecki, Radosław, 'Aleksander z Malonne - "persona mixta”: Wojowniczy biskup na krańcach chrześcijańskiego świata i jego kronikarski portret', St. Źr., 55, 2017, pp. 51-78.

Kotecki, Radosław, 'Lions and Lambs, Wolves and Pastors of the Flock: Portraying Military Activity of Bishops in Twelfth-Century Poland', in Between Sword and Prayer: Warfare and Medieval Clergy in Cultural Perspective, ed. Radosław Kotecki, Jacek Maciejewski and John S. Ott, Leiden and Boston, MA: Brill, 2018, pp. 303-40. Kotecki, Radosław, 'Ordynariusz płocki Szymon w Gallowej narracji o bitwie Mazowszan z Pomorzanami (Gall II, 49)', in Ecclesia et bellum: Kościót wobec wojny i zaangażowania militarnego duchowieństwa $w$ wiekach średnich, ed. Radosław Kotecki and Jacek Maciejewski, Bydgoszcz: Wydawnictwo UKW, 2016, pp. 142-67.

Kotecki, Radosław, ‘Żydzi, świętokradcy i pokój książęcy: Wokół instytucji protekcji monarszej w Polsce piastowskiej', in Oryginalność i wtórność polskiej kultury politycznej i religijnej od X do XIII wieku, ed. Roman Michałowski and Grzegorz Pac, Warsaw: Wydawnictwa UW, 2020, pp. 27-75.

Kotecki, Radosław and Jacek Maciejewski, 'Writing Episcopal Courage in Twelfth-Century Poland: Gallus Anonymous and Master Vincentius', in Episcopal Power and Personality in Medieval Europe, 900-1480, ed. Peter Coss et al., Turnhout: Brepols, 2020, pp.35-61.

Kotecki, Radosław, Jacek Maciejewski and John S. Ott, 'The Medieval Clergy and War: A Historiographical Introduction', in Between Sword and Prayer: Warfare and Medieval Clergy in Cultural Perspective, ed. Radosław Kotecki, Jacek Maciejewski and John S. Ott, Leiden and Boston, MA: Brill, 2018, pp. 1-23.

Kowalska, Barbara, 'Biskup w oczach hagiografów', Prace Naukowe Akademii im. Jana Długosza w Częstochowie. Zeszyty Historyczne, 13, 2014, pp. 13-29.

Krafl, Pavel, 'Prawo kościelne w Czechach i na Morawach w średniowieczu', Echa Przeszłości, 11, 2010, pp. 19-36.

Kras, Paweł, Husyci w piętnastowiecznej Polsce, Lublin: TN KUL, 1998.

Kwiatkowski, Stefan, Powstanie i kształtowanie się chrześcijańskiej mentalności religijnej w Polsce do końca XIII w., Warsaw, Poznań and Toruń: PWN, 1980.

Kwiatkowski, Stefan, 'Utracona wiarygodność statutów Jakuba z Leodium', Klio, 7, 2005, 7, pp. 159-64.

Labuda, Gerard, 'O katalogach biskupów krakowskich przed Długoszem', St. Źr., 27, 1983, pp. 83-96.

Langton, John, 'English Bishops' Hunting Rights, Hunts, and Hunting Grounds', in Princes of the Church: Bishops and Their Palaces, ed. David W. Rollason, London and New York: Routledge, 2017, pp. 115-26. 
Larson, Atria A., 'Killing a Career: Homicide and the Development of Medieval Clerical Discipline', The Jurist: Studies in Church Law and Ministry, 74, 2014, 2, pp. 265-88.

Lund, Niels, 'Absalon som kriger og politiker', in Absalon: Fcedrelandets fader, ed. Frank Birkebæk, Tom Christensen and Inge Skovgaard-Petersen, [Roskilde]: Roskilde museums forlag, 1996, pp. 73-90.

Lutterbach, Hubertus, 'Die für Kleriker bestimmten Verbote des Waffentragens, des Jagens sowie der Vogel- und Hundehaltung (a. 500-900)', Zeitschrift für Kirchengeschichte, 109, 1998, 2, pp. 149-66.

Maciejewski,Jacek, 'A Bishop Defends His City, or Master Vincentius's Troubles with the Military Activity of His Superior', in Between Sword and Prayer: Warfare and Medieval Clergy in Cultural Perspective, ed. Radosław Kotecki, Jacek Maciejewski and John S. Ott, Leiden and Boston, MA: Brill, 2018, pp. 341-68.

Maciejewski, Jacek, 'Biskup krakowski Pełka a bitwa nad Mozgawą w 1195 roku', KH, 124, 2018, 3, pp. 411-38.

Maciejewski, Jacek, 'Biskupi polscy na wojnach monarchów w XIII-XIV wieku', Res Historica, 51, 2021 (in print).

Maciejewski, Jacek, Episkopat polski doby dzielnicowej, 1180-1320, Cracow: Societas Vistualana; Bydgoszcz: Akademia Bydgoska im. Kazimierza Wielkiego, 2003.

Maciejewski, Jacek, 'Making War and Enormities: Violence within the Church in the Diocese of Cracow at the Beginning of the 14th Century', in 'Ecclesia et Violentia': Violence against the Church and Violence within the Church in the Middle Ages, ed. Radosław Kotecki and Jacek Maciejewski, Newcastle upon Tyne: Cambridge Scholars Publishing, 2014, pp. 141-65.

Maciejewski, Jacek, "Memory of "Warrior-Bishops" of Płock Included into Jan Długosz's Works', in Christianity and War in Medieval East Central Europe and Scandinavia, ed. Radosław Kotecki, Carsten Selch Jensen and Stephen Bennett, Leeds: ARC Humanities Press and Amsterdam University Press, 2021 (in print).

Magistri Vincentii dicti Kadłubek Chronica Polonorum, ed. Marian Plezia, Cracow: PAU, 1994, MPH s.n., vol. 11.

Mesley, Matthew M., 'Beyond Celibacy: Medieval Bishops, Power and Masculinity in the Middle Ages', in The Palgrave Handbook of Masculinity and Political Culture in Europe, ed. Christopher Fletcher et al., London: Palgrave Macmillan, 2018, pp. 133-60.

Michałowski, Roman, 'Święty Wojciech - biskup reformator w Europie X wieku', in Granica wschodnia cywilizacji zachodniej w średniowieczu, ed. Zbigniew Dalewski, Warsaw: Instytut Historii PAN, 2014, pp. 169-210.

Miller, Andrew G., 'Deer Parks and Masculine Egos: Knights, Priors, and Bishops in the Medieval North of England', in Princes of the Church: Bishops and Their Palaces, ed. David W. Rollason, London and New York: Routledge, 2017, pp. 127-41.

Miller, Andrew G., 'Knights, Bishops and Deer Parks: Episcopal Identity, Emasculation and Clerical Space in Medieval England', in Negotiating Clerical Identities: Priests, Monks and Masculinity in the Middle Ages, ed. Jennifer D. Thibodeaux, Basingstoke and New York: Palgrave Macmillan, 2010, pp. 204-37. 
Mors et miracula beati Verneri, episcopi Plocensis auctore Iohanne, decano Plocensi, ed. Wojciech Kętrzyński, in MPH, vol. 4, Lwów: Akademia Umiejętności, 1884, pp. 748-54.

Múcska, Vincent, Uhorsko a cirkevné reformy 10. a 11. storočia, Brno: Stimul, 2004.

Najstarszy zwód prawa polskiego, ed. Józef Matuszewski and Jacek S. Matuszewski, Łódź: Wydawnictwo UŁ, 1995.

Nakashian, Craig M., Warrior Churchmen of Medieval England, 1000-1250: Theory and Reality, Woodbridge: Boydell Press, 2016.

Noonan, John T., 'Who was Rolandus?', in Law, Church, and Society: Essays in Honor of Stephan Kuttner, ed. Kenneth Pennington and Robert Somerville, Philadelphia, PA: University of Pennsylvania Press,1977, pp. 21-48.

Nowacki, Józef, ‘Biskup Andrzej Bniński w walce z husytami Zbąszynia: Nieznane karty procesów husyckich z roku 1439', RH, 10, 1934, 2, pp. 248-78.

Ott, John S., Bishops, Authority, and Community in Northwestern Europe, c. 1050-1150, Cambridge: Cambridge University Press, 2015.

Ożóg, Krzysztof, 'Dopełnienie szamotulskie - studium źródłoznawcze’, SH, 35, 1992, 2, pp. 143-53.

Ożóg, Krzysztof, Kultura umysłowa w Krakowie w XIV wieku: Środowisko duchowieństwa świeckiego, Wrocław: Zakład Narodowy im. Ossolińskich, Cracow: PAN, 1987.

Pakulski, Jan, 'Mikołaj z Wenecji - krwawy diabeł: Ze studiów nad genealogią Nałęczów', Prace Komisji Historii Bydgoskiego Towarzystwa Naukowego, 7, 1970, pp. 53-61.

Parisse, Michel, 'The Bishop: Prince and Prelate', in The Bishop: Power and Piety at the First Millennium, ed. Sean Gilsdorf, Münster: Lit, 2004, pp. 1-22.

Pauk, Marcin Rafał, review of Włodzimierz Bielak, Biskup i jego urzad w oczach średniowiecznych kronikarzy polskich, Lublin, 2011, PH, 104, 2014, 3, pp. 597-601.

Pauk, Marcin Rafał, 'Capella regia i struktury Kościoła monarszego w Europie Środkowej X-XII wieku: Ottońsko-salickie wzorce ustrojowe na wschodnich rubieżach łacińskiego chrześcijaństwa', in Granica wschodnia cywilizacji zachodniej w średniowieczu, ed. Zbigniew Dalewski, Warsaw: Instytut Historii PAN, 2014, pp. 211-77.

Pauk, Marcin Rafał, “"Quicquid pertinebat ad imperium”: Kościół w Polsce a Rzesza do połowy XII wieku', in Chrzest Mieszka I i chrystianizacja państwa Piastów, ed. Józef Dobosz, Jerzy Strzelczyk and Marzena Matla-Kozłowska, Poznań: Wydawnictwo Naukowe UAM, 2017, pp. 249-80.

Pauk, Marcin Rafał, and Ewa Wółkiewicz, “"Ministri enim altaris ministri curie facti sunt”: Ottońsko-salicki “system” Kościoła Rzeszy i jego oddziaływanie w Europie Środkowej XI-XII wieku', in Kościół w monarchiach Przemyślidów i Piastów, ed. Józef Dobosz, Poznań: Wydawnictwo Poznańskie, 2009, pp. 105-38.

Perron, Anthony, ‘Saxo Grammaticus's Heroic Chastity: A Model of Clerical Celibacy and Masculinity in Medieval Scandinavia', in Negotiating Clerical Identities: Priests, Monks and Masculinity in the Middle Ages, ed. Jennifer D. Thibodeaux, Basingstoke and New York: Palgrave Macmillan, 2010, pp. 113-35. 
Pietras, Tomasz, ‘Krwawy wilk z pastorałem’: Biskup krakowski Jan zwany Muskata, Warsaw: Semper, 2001.

Plezia, Marian, ‘Księgozbiór katedry krakowskiej wedle inwentarza z r. 1110', in Silva rerum. Series nova, ed. Tadeusz Ulewicz, Cracow: Wydawnictwo Literackie, 1981, pp. 16-29.

Pluskowski, Aleksander, Wolves and the Wilderness in the Middle Ages, Woodbridge: Boydell Press, 2006.

Reuter, Timothy, 'A Europe of Bishops: The Age of Wulfstan of York and Burchard of Worms', in Patterns of Episcopal Power: Bishops in Tenth and Eleventh Century Western Europe, ed. Ludger Körntgen and Dominik Waßenhoven, Berlin and Boston, MA: De Gruyter, 2011, pp. 17-38.

Rocznik kapituły gnieźnieńskiej, in Roczniki wielkopolskie, ed. Brygida Kürbis, Warsaw: PWN, 1962, pp. 1-9, MPH s.n., vol. 6.

Rocznik kapituły krakowskiej, in Najdawniejsze roczniki krakowskie i kalendarz, ed. Zofia Kozłowska-Budkowa, Warsaw: PWN, 1978, pp. 21-105, MPH s.n., vol. 5.

Rocznik małopolski, ed. August Bielowski, in MPH, vol. 3, Lwów: Akademia Umiejętności, 1878, pp. 135-202.

Rosik, Stanisław, Bolesław Krzywousty, Wrocław: Chronicon, 2013.

Russell, Frederick K., The Just War in the Middle Ages, Cambridge: Cambridge University Press, 1977.

Saxo Grammaticus, Gesta Danorum, 2 vols, ed. Karsten Friis-Jensen, Oxford: Clarendon Press, 2015.

Schlesisches Urkundenbuch, 6 vols, Cologne: Böhlau, 1963-98, vol. 5: 1282-1290, 1993, ed. Heinrich Appelt, Josef Joachim Menzel and Winfried Irgang.

Schlesisches Urkundenbuch, 6 vols, Cologne: Böhlau, 1963-98, vol. 6: 1291-1300, ed. Heinrich Appelt, Josef Joachim Menzel and Winfried Irgang.

II Catalogus episcoporum Wladislaviensium (Volboriensis), ed. Wojciech Kętrzyński, in MPH, vol. 4, Lwów: Akademia Umiejętności, 1884, pp. 24-30.

Semkowicz, Władysław, 'Nieznany testament biskupa wrocławskiego (12701292)', Collectanea Theologica, 17, 1936, 1-2, pp. 263-72.

Skwierczyński, Krzysztof, 'Centrum i prowincja - rewolucja gregoriańska w Kościele powszechnym a reforma gregoriańska w Kościele polskim’, in Kościół w monarchiach Przemyślidów i Piastów, ed. Józef Dobosz, Poznań: Wydawnictwo Poznańskie, 2009, pp. 181-92.

Smirnova, Victoria, 'No Way to Salvation for German Bishops? The Case of St. Engelbert of Cologne', in Saintly Bishops and Bishop's Saints, ed. John S. Ott and Trpimir Vedriš, Zagreb: Hagiotheca, 2012, pp. 183-200.

Sot, Michel, 'Des évêques à la guerre (VIII'-XIII ${ }^{\mathrm{e}}$ siècle)', in Guerre et société au Moyen Âge: Byzance - Occident (VIII ${ }^{e}-X I I I^{e}$ siècle), ed. Dominique Barthélemy and Jean-Claude Cheynet, Paris: Association des amis du Centre d'histoire et civilisation de Byzance, 2010, pp. 103-12.

Stróżyk, Paweł, 'Monogram z roty arcybiskupa gnieźnieńskiego Henryka Kietlicza z 1208 roku', $R H, 77,2011$, pp. 169-81. 
Szabó, Thomas, 'Die Kritik der Jagd: Von der Antike zum Mittelalter', in Jagd und höfische Kultur im Mittelalter, ed. Werner Rösener, Göttingen: Vandenhoeck \& Ruprecht, 1997, pp.167-229.

Szymaniak, Marek, Biskup płocki Gedko (1206-1223): Działalność kościelno-polityczna na tle procesu emancypacji Kościoła polskiego spod władzy książęcej, Toruń: Adam Marszałek, 2007.

Szymański, Józef, 'Biskupstwa polskie w wiekach średnich: Organizacja i funkcje’, in Kościół w Polsce, 2 vols, Cracow: Znak, 1968-70, vol. 1: Średniowiecze, ed. Jerzy Kłoczowski, pp. 127-233.

Szymczak, Jan, 'W kwestii liczebności oddziałów wojskowych w Polsce okresu rozbicia dzielnicowego', Acta Universitatis Lodziensis. Folia Historica, 2, 1981, pp. 51-75.

Tęgowski, Jan, ‘Postawa polityczna arcybiskupa gnieźnieńskiego Bodzęty w czasie bezkrólewia po śmierci Ludwika Węgierskiego', in Genealogia - rola związków rodzinnych i rodowych $w$ życiu publicznym $w$ Polsce średniowiecznej na tle porównawczym, ed. Andrzej Radzimiński and Jan Wroniszewski, Toruń: Wydawnictwo UMK, 1996, pp. 131-43.

Taylor Louisa, 'Bishops, War, and Canon Law: The Military Activities of Prelates in High Medieval Norway', Scandinavian Journal of History, 7, 2019, 2, pp. 1-23.

Tomaszek, Michał, 'Modlitwa i łzy bronią biskupa: Pasterze polskiego Kościoła a walka orężna w ujęciu Wincentego Kadłubka’, RH, 71, 2005, pp. 121-36.

Vetera monumenta Polonice et Lithuanice gentiumque finitimarum historiam illustrantia, 4 vols, ed. August Theiner, Rome: Typis Vaticanis, 1860-64, vol. 1.

Vetulani, Adam, 'Przenikanie zasad powszechnego prawa kanonicznego i prawa rzymskiego do piastowskiej Polski', in Adam Vetulani, Z badań nad kultura prawnicza $w$ Polsce piastowskiej, Wrocław: Zakład Narodowy im. Ossolińskich, 1976, pp. 95-128.

Vetulani, Adam, 'W poszukiwaniu nowych źródeł', in Adam Vetulani, Z badań nad kultura prawnicza w Polsce piastowskiej, Wrocław: Zakład Narodowy im. Ossolińskich, 1976, pp. 75-94.

Vita et miracula sanctce Kyngæe ducissce Cracoviensis, ed. Wojciech Kętrzyński, in MPH, vol. 4, Lwów: Akademia Umiejętności, 1884, pp. 662-744.

Vita S. Stanislai episcopi Cracoviensis (Vita maior), ed. Wojciech Kętrzyński, in MPH, vol. 4, Lwów: Akademia Umiejętności, 1884, pp. 319-438.

Vita S. Stanislai episcopi Cracoviensis (Vita minor), ed. Wojciech Kętrzyński, in MPH, vol. 4, Lwów: Akademia Umiejętności, 1884, pp. 238-85.

Vogt, Helle, 'Absalon: évêque, guerrier et le Richelieu du Danemark', in Autour de Lanfranc (1010-2010): Réforme et réformateurs dans l'Europe du Nord-Ouest (XI ${ }^{e}$-XII ${ }^{e}$ siècles), ed. Julia Barrow, Fabrice Delivré and Véronique Gazeau, Caen: Presses Universitaires de Caen, 2015, pp. 329-42.

Webb, Jeffrey R., 'Representations of the Warrior-Bishop in Eleventh-Century Lotharingia', Early Medieval Europe, 24, 2016, 1, pp. 103-30.

Weigand, Rudolf, 'Magister Rolandus und Papst Alexander III', Archiv für katholisches Kirchenrecht, 149, 1980, pp. 3-44. 
Wójcik, Walenty, 'Udzielanie pomocy monarszej Kościołowi w Polsce średniowiecznej', Prawo Kanoniczne, 3, 1960, 1-2, pp. 71-86.

Wółkiewicz, Ewa, 'Niegodna rozrywka czy instrument władzy? Biskupi i łowy w późnym średniowieczu', in Rzeczy i ludzie: Kultura materialna w późnym średniowieczu i w okresie nowożytnym: Studia dedykowane Marii Dąbrowskiej, ed. Wojciech Bis and Magdalena Bis, Warsaw: IAE PAN, 2014, pp. 205-17.

Wünsch, Thomas, 'Der heilige Bischof - Zur politischen Dimension von Heiligkeit im Mittelalter und ihrem Wandel', Archiv für Kulturgeschichte, 82, 2000, 2, pp. 261-302.

Wyrozumski, Jerzy, 'Pontyfikat arcybiskupi i reformy Henryka Kietlicza', in 1000 lat Archidiecezji Gnieźnieńskiej, ed. Jerzy Strzelczyk and Janusz E. Górny, Gniezno: Gaudentinum, 2000, pp. 97-105.

Biographies: Dr Radosław Kotecki - assistant professor at the Medieval History Department, Faculty of History of the Kazimierz Wielki University in Bydgoszcz. Research interests: cultural and social history of the Middle Ages, religion and conduct of war, military activity of clergymen, legislation and penalties in the Middle Ages, the king's peace, ideology of power, violence; contact: radoslaw_kotecki@ukw.edu.pl.

Professor Jacek Maciejewski - full professor, head of the Medieval History Department, Faculty of History of the Kazimierz Wielki University in Bydgoszcz. Research interests: the clergy and the Church versus war and violence in the Middle Ages, career models of higher-rank clergy and clerical participation in the social, cultural and political life of medieval Poland (with particular focus on episcopacy), church rituals, history of the Cuiavia monarchy of the last Piast kings; contact:jmac@ukw.edu.pl. 